Revista lus et Praxis, Año 21, No 1, 2015, pp. 57 - 100

ISSN 0717 - 2877

Universidad de Talca - Facultad de Ciencias Jurídicas y Sociales

"Del resarcimiento en Chile de los daños causados en el matrimonio"

David G. Vargas Aravena

Trabajo recibido el 9 de julio y aprobado el 29 de noviembre de 2014

\title{
Del resarcimiento en Chile de los daños causados en el matrimonio*
}

\author{
CHILE RECOUPMENT OF DAMAGES IN MARRIAGE
}

David G. Vargas Aravena**

\section{Resumen}

El presente trabajo tiene por objeto describir qué sucede en Chile frente a los daños causados al interior del matrimonio, en especial en lo relativo a la infracción de sus efectos personales, revisando los fundamentos de las diversas posturas que sobre el particular comienzan a desarrollarse por la doctrina y jurisprudencia nacional, distinguiendo aquellos escenarios en los cuales el resarcimiento se admite en términos más o menos generales, de aquellos donde se concentra la discusión, manifestando en último término, la postura del autor sobre esta cuestión, como la naturaleza de la acción de responsabilidad, y sus presupuestos para este caso.

\section{ABSTRACT}

This paper aims to describe what happens in Chile against damage within marriage, especially as regards the infringement of his personal effects, reviewing the basics of the various positions on the subject begin to develop the doctrine and jurisprudence, distinguishing those scenarios in which compensation is supported by more or less broadly than where the discussion is concentrated, stating ultimately the author's position on this issue, as the nature of the action responsibility and budgets to this case.

\section{Palabras Clave}

Responsabilidad, Matrimonio, Deberes conyugales, Incumplimientos, Daños

\section{KeYWORDS}

Responsibility, Marriage, Conjugal duties, Breaches, Damage

\section{Planteamiento general}

Como ya señalé el año $2006^{1}$ y $2009^{2}$, nadie puede discutir ni dudar que, vigente el matrimonio, sus miembros se hallan expuestos, en consideración a las características que el mismo vínculo presenta, a incurrir en hechos u omisiones

* Este trabajo ha sido realizado en el marco del Proyecto Fondecyt № 11121560.

** Profesor de Derecho civil en la Universidad Católica de la Santísima Concepción, Concepción, Chile. Doctor en Derecho (Universidad de Salamanca, España). Correo electrónico: davidvargasaravena@ hotmail.com.

1 Véase VARGAS (2006), pp. 7-36.

${ }^{2}$ Véase VARGas (2009). 
de los cuales se pueda causar algún daño o perjuicio para cualquiera de los cónyuges, sean o no consecuencia del incumplimiento de los deberes conyugales, o de la falta de diligencia en la administración de los bienes matrimoniales.

En efecto, si bien, tanto en el ámbito de los efectos personales como patrimoniales del matrimonio, los cónyuges pueden realizar actos u omisiones que causen daños entre sí, este trabajo se va a limitar al campo de los efectos personales del matrimonio, o dicho de otra forma, de los daños patrimoniales o extrapatrimoniales causados por incumplimiento de los deberes y derechos conyugales. No desconocemos que bajo el ámbito económico patrimonial los cónyuges también se pueden causar los más diversos daños, ya sean consecuencia de su mala administración, de actos en fraude de los derechos de su consorte, o de daños cometidos dolosamente a la sociedad, pero reconocemos que un adecuado y merecido estudio sobre el particular excede con creces los límites de esta investigación.

En otras palabras, este trabajo tiene por objeto determinar si los daños causados entre cónyuges por incumplimiento de los deberes personales del matrimonio, deben someterse a las reglas comunes de la responsabilidad civil (que obligan, como es bien sabido, a reparar cualquier daño, corporal, patrimonial o extrapatrimonial imputablemente ocasionado) o, por el contrario, existen razones que llevan a excluir, atenuar o, en todo caso, modificar su aplicación.

Advertimos que la doctrina chilena escasamente se ha preocupado por el tema de los daños que se puedan ocasionar los cónyuges entre sí, o incluso entre personas unidas por otros vínculos familiares, como el parentesco, entiéndase padres e hijos, hermanos, entre otros, e incluso entre personas unidas por lazos de afectividad y convivencia, como es el caso de las uniones de hecho; cualquier estudio bibliográfico, demuestra la efectividad de nuestra afirmación, debido probablemente a que el Derecho de daños (como se denomina hoy a las materias concernientes a la responsabilidad civil) se aviene mal con el Derecho de familia, en atención a que este último, según tradicionalmente se ha enseñado, está inspirado en principios que exceden a cuestiones meramente patrimoniales, como que sus normas sean de orden público, la limitación del principio de autonomía de la voluntad, y el carácter intuito personae.

Sin embargo, como los principios que inspiran las normas generales del Derecho de daños, tales como alterum non laedere, de indemnidad e integridad del daño, reaccionan frente a la existencia de un perjuicio, independiente del escenario en que ello suceda, creemos que un estudio, aunque sea sólo de ciertas situaciones al interior del matrimonio, resulta indispensable.

Dicho lo anterior, advertimos, además, que nos abocaremos exclusivamente a la relación existente entre responsabilidad civil y los daños que los cónyuges se puedan ocasionar constante matrimonio por incumplimiento de los deberes conyugales, con independencia de que se haya presentado o no demanda de 
divorcio por cualquiera de los cónyuges, lo cual es coherente con el hecho de que la fuente del daño alegado no es el divorcio, sino que los hechos que en su caso podrían motivar dicha causal de terminación; en este sentido, compartimos la opinión de Turner Saelzer ${ }^{3}$ y Corral Talciani ${ }^{4}$ quienes rechazan que la acción de divorcio en sí misma pueda dar lugar a una acción de responsabilidad; el último de los autores citados es muy claro al señalar que no es el divorcio "el que permitiría reclamar daños, ya que éste es ahora una facultad legal y no podría calificarse de hecho ilícito o contrario a derecho positivo" ${ }^{\prime \prime}$.

Consecuencia de lo anterior, descartamos que el ejercicio de la acción de divorcio, ya sea por culpa o no, sea un requisito de admisibilidad o de trámite previo obligatorio para el ejercicio de la acción de indemnización de perjuicios, toda vez que entendemos que lo que se discute es si el daño causado por el incumplimiento de los deberes conyugales debe ser resarcido o no, con independencia de si esos mismos incumplimientos sean causa para una acción de divorcio, y si ésta se haya ejercido o no, pese a que en sentido contrario se manifiestan Ramos $\operatorname{Pazos}^{6}$ y la Corte de Apelaciones de Valdivia ; así pues, éstos sostienen que la discusión sólo puede plantearse en el caso del divorcio por culpa, afirmación que no compartimos ya que creemos que descansa en una confusión entre los daños causados por incumplimiento de los deberes conyugales, los que son objeto de la discusión si son o no resarcibles, de los daños causados por el ejercicio de la acción de divorcio, los que en ningún caso son resarcibles por las razones ya expresadas precedentemente, a diferencia de lo que acontece en el ordenamiento jurídico francés, donde en su artículo $266^{8}$ del Code se reconoce una particular acción indemnizatoria frente a determinados daños causados con ocasión del ejercicio de una acción de divorcio.

\footnotetext{
3 TURNer (2012), p. 170.

${ }^{4}$ Corral (2008), pp. 81-89; Corral (2011), p. 118 y ss.; por citar algunas de las obras en el que citado autor manifiesta su opinión en este sentido.

${ }^{5}$ Se opone a entender al divorcio como una facultad legal VAlenZuela (2012), p. 256 y ss., al sostener que es posible encontrar ciertos supuestos de daños por un ejercicio abusivo de la acción de divorcio unilateral.

${ }^{6}$ Ramos (2007), p. 116.

7 Sentencia de fecha 8 de agosto de 2007, causa rol № 411-2007.

${ }^{8}$ Artículo 266 Cc. francés: "Sin perjuicio de la aplicación del artículo 270, puede acordarse una indemnización de daños y perjuicios a favor de uno de los cónyuges, en reparación de las consecuencias particularmente graves sufridas por el hecho de la disolución del matrimonio, ya cuando hubiera sufrido una demanda de divorcio por alteración definitiva del vínculo conyugal sin haber formulado a su vez, ninguna demanda de divorcio, o cuando el divorcio se hubiera declarado por culpa exclusiva de su cónyuge. Esta petición sólo podrá formularse con ocasión del divorcio".
} 
En definitiva, por las razones expuestas para el ordenamiento nacional, desatenderemos las consecuencias de la declaración de divorcio, y por consideraciones de extensión, excluiremos los efectos de la declaración de nulidad matrimonial; no obstante, reconocemos que de ambas situaciones podrían generarse daños a cualquiera de los cónyuges, ya sea por la frustración de la esperanza de lograr una familia legítimamente constituida o, por la destrucción de los lazos matrimoniales en razón y circunstancias que normalmente no permitirían rehacer su vida o, en haber sufrido comentarios equívocos o escandalosos a consecuencia del respectivo procedimiento, entre otros, pero de ahí que estos daños sean indemnizables en cualquier caso, es otra cosa.

\section{De la irresarcibilidad de los daños entre cónyuges por incumplimiento de los deberes conyugales}

El contenido de este apartado tiene por objeto describir los principales argumentos dogmáticos de aquella doctrina que podríamos denominar clásica o tradicional, que rechaza la aplicación de las normas de responsabilidad civil por los daños que los cónyuges se causen entre sí por incumplimiento de los deberes conyugales, ya sea, porque discuten la calidad de obligación de los deberes conyugales, fundado en su preeminencia ético-moral por sobre la jurídica, como en su falta de coercibilidad o imposibilidad de cumplimiento compulsivo; porque sostienen la aplicación del principio de especialidad del Derecho de familia; que los principios del derecho de familia impiden las acciones de responsabilidad civil; junto a estos argumentos, también comienzan a invocarse otros, tales como que se produciría un aumento de la litigiosidad conyugal, o que constituiría un desincentivo para la acción de divorcio por cese efectivo por sobre el por culpa o falta, o que obligaría a reparar cualquier daño o molestia que se cause al interior del matrimonio, respecto de los cuales atendido su escaso desarrollo omitiremos su estudio por el momento.

Enunciados los argumentos de posición, pasemos a desarrollar aquellos que hemos denominado principales, sin perjuicio de señalar nuestra opinión crítica frente a cada uno de ellos.

1.- En cuanto a la discutida calidad de obligación de los deberes conyugales fundado en su preeminencia ética-moral por sobre la jurídica, como en su falta de coercibilidad o imposibilidad de cumplimiento compulsivo:

Este argumento tiene su mayor fundamento en las palabras de Abeliuk Manasevich $^{9}$ quien, distinguiendo el deber jurídico de la obligación, señala que "el deber jurídico es una norma de conducta impuesta coactivamente por el

${ }_{9}$ Abeliuk (1983), p. 55 y ss. 
legislador, en el sentido de que se sanciona su inobservancia", dentro del cual se comprenden tres categorías o especies: los deberes generales de conducta, los deberes específicos de conducta, y las obligaciones en su sentido técnico estricto. Que en el caso de los deberes específicos de conducta, el legislador los "suele calificar de obligaciones, aunque no lo son técnicamente; por ello creemos que es preferible conservarles la designación de deberes específicos, a falta de otra denominación mejor. Tales son la mayor parte de los deberes de familia que rigen las relaciones no pecuniarias entre padres e hijos, cónyuges entre sí, etc. Se diferencian fundamentalmente de las obligaciones propiamente tales, en que por el contenido moral y afectivo que suponen, no son susceptibles ni de ejecución forzada ni de indemnización de perjuicios en caso de infracción".

En efecto, para el citado autor, la preeminencia del contenido ético-moral, como la imposibilidad de cumplimiento compulsivo, serían los dos elementos distintos de los deberes conyugales que los lleva a calificar sólo como deberes específicos de conducta pero no de obligaciones, haciendo imposible el ejercicio de una acción indemnizatoria frente a su incumplimiento, ya que para ello sería necesario la infracción de una obligación (entendiéndola en sentido técnico) o del deber general de conducta, y no sólo de un deber específico como lo serían los deberes conyugales.

A similar conclusión arriba Hernández Paulsen ${ }^{10}$ en cuanto frente al incumplimiento de los deberes conyugales no es posible el ejercicio de una acción indemnizatoria, atendido el contenido preeminente moral por sobre el jurídico, como por la inexistencia de un mecanismo jurídico que permita su cumplimiento en naturaleza; eso sí, reconoce a los deberes conyugales "cierta juridicidad" o "juridicidad restringida", limitada a los casos de infracción de mayor entidad, que darían lugar a una acción de separación o divorcio.

Agrega que la preeminencia ético-moral por sobre la jurídica se constata de diversas situaciones que consagra la Nueva Ley de Matrimonio Civil, como por ejemplo que en caso de separación de hecho de los cónyuges mutuamente consentida se les dispensa del deber de fidelidad, del deber de vivir en el hogar común, cuyo cumplimiento queda entregado a la voluntad o consideración moral de los cónyuges; o que en caso de separación de hecho o judicial o divorcio, el acuerdo exigido por el legislador para estos casos tampoco contiene ninguna referencia al deber de fidelidad, por lo que frente a estas situaciones de crisis, el cumplimiento o incumplimiento de este deber es irrelevante para el legislador. De la misma forma, sostiene que el hecho que el derecho solo reaccione frente a una violación grave de los deberes y obligaciones que impone el

10 Hernández (2014). 
matrimonio en la medida que torne intolerable la vida en común (artículos 26 y 54 de la Ley de Matrimonio Civil), o frente a una transgresión grave y reiterada de los deberes de convivencia, socorro y fidelidad propia del matrimonio, "dan cuenta de que el legislador no asocia ninguna consecuencia a las infracciones de deberes conyugales que no presenten la señalada entidad, solución que resulta ser, nuevamente, el corolario de la preeminencia de la faceta moral al interior de tales deberes, lo cual confirma la juridicidad restringida de estos".

El mismo Hernández Paulsen ${ }^{11}$ añade que los deberes conyugales, ya se entiendan como deberes con "cierta juridicidad" o "juridicidad restringida", o incluso como "obligaciones", la conclusión es la misma, la improcedencia de la acción indemnizatoria frente a su incumplimiento, atendido que son imposibles de exigir compulsivamente, lo que conlleva la "imposibilidad de exigir el cumplimiento por equivalencia de los mismos, al constituir este último un reemplazo de la primera", quedando su cumplimiento siempre entregado a la voluntad de los sujetos vinculados por ellas; que el "único sentido que tiene hablar de "cumplimiento por equivalencia" consiste en que este es un reemplazo de la exigibilidad en naturaleza de una obligación, de manera que si esta exigibilidad nunca ha sido posible (como ocurre en el caso de los deberes conyugales), carece de lógica hablar de "reemplazo" de la misma, es decir, de la subrogación de una conducta cuya exigibilidad nunca pudo tener lugar". Advierte, que si bien podría sostenerse que la imposibilidad de exigir compulsivamente el cumplimiento de los deberes justifica admitir su cumplimiento por equivalencia, como sucede con todas aquellas obligaciones cuyo cumplimiento en naturaleza ya no resulta posible, este argumento no es aplicable al presente caso, ya que "la imposibilidad de cumplimiento forzado generadora de la subrogación indemnizatoria (en su faceta compensatoria) es una imposibilidad posterior al nacimiento de la obligación, cosa que no ocurre en el caso de los deberes conyugales, en que la imposibilidad de cumplimiento forzado de los mismos existe desde su nacimiento, es decir, desde la celebración del matrimonio".

Dentro de esta misma postura encontramos también a Martinic Galetovic, Weinstein Weinstein ${ }^{12}$ y Ramos Pazos ${ }^{13}$, quienes también destacan exclusivamente de los deberes conyugales su fuerza moral basada en el afecto y en la responsabilidad individual, cuyo cumplimiento queda entregado fundamentalmente a la conciencia de los cónyuges, dejando al margen su relevancia jurídica. En este sentido, sostienen el desconocimiento -o la irrelevancia, a lo menos- del carácter jurídico de los deberes conyugales, fundado en que su naturaleza es

\footnotetext{
11 HeRNÁNDEZ (2014).

12 Martinic y Weinstein (2004), p. 29 y ss.

13 Ramos (2007), p. 142.
} 
de simples deberes ético-morales que no producen obligación jurídica alguna, cuyo cumplimiento queda entregado a la conciencia de los cónyuges, incoercibles en su esencia, haciendo imposible el ejercicio de cualquier acción por su incumplimiento.

Ahora bien, en el orden jurisprudencial, esta tesis fue expresamente recogida en la sentencia de 10 de noviembre de 2009 de la Corte de Apelaciones de Santiago ${ }^{14}$, la que precisamente conociendo de una acción de indemnización de perjuicios patrimoniales y morales interpuesta por el marido en contra de su mujer y un tercero fundado en la responsabilidad civil extracontractual de éstos por causa del ilícito civil de adulterio, el que además provocó una confusión de paternidad con el reconocimiento de una hija que resultó ser ajena, resolvió desestimar la demanda indemnizatoria toda vez que en virtud "de las opiniones de los juristas Arturo Alessandri y Roberto de Ruggiero, las relaciones de familia tiene un fuerte componente ético que sobrepasa, con mucho, el ámbito estrictamente jurídico" (considerando décimo quinto). Así pues, citando precisamente a Roberto de Ruggiero, según da cuenta el considerando cuarto, los sentenciadores hacen suyas las palabras del autor italiano donde expresa que "antes que jurídico, la familia es un organismo ético. De la ética, en efecto, proceden los preceptos más esenciales que la ley presupone y a los cuales hace constante referencia, apropiándoselos a veces y transformándolos de este modo en preceptos jurídicos; por ello se explica el fenómeno peculiar en el derecho de familia, de haber preceptos sin sanción o con sanción atenuada, obligaciones incoercibles, porque el derecho, o es por sí mismo incapaz de provocar mediante la coerción la observancia de dichos preceptos, o cree más conveniente confiar su observancia al sentido ético, a la costumbre, a otras fuerzas que actúan en el ambiente social".

En este sentido, se debe tener presente que la tesis seguida por este grupo de autores, como por la Corte de Apelaciones de Santiago, es fruto de la influencia de la Escuela Histórica ${ }^{15}$ quien se encargó de poner en duda el carácter jurídico de estos deberes, fundados en que éstos encontraban su argumento en la costumbre o la ética, y no en el derecho positivo. Entendían que "virtudes como la fidelidad, la devoción, la obediencia, el respeto se imponían por la costumbre, y no por la ley, y que, en sustancia, debiera dejarse la ordenación de las relaciones familiares, en primera línea, a los miembros de la familia y a su sentido moral... la libertad pertenece al individuo como una prerrogativa innata, siendo

${ }^{14}$ Causa rol corte $N^{0}$ 7738-2007. Se debe agregar que sobre la citada sentencia se interpuso recurso de casación en el fondo el que fue desestimado por la Corte Suprema con fecha 13 de junio de 2012, causa rol No 263-2010.

15 Para ver qué se entiende por Escuela Histórica véase a SAvigny (1908), p. 16. 
misión única del Derecho asegurar su titularidad y disciplinar su ejercicio"16. Muy ilustrativas de esta posición son las palabras de Savigny, al expresar "no niego que la fidelidad y la asistencia recíproca de los esposos, la obediencia y el respeto de los hijos pertenezcan a la esencia del matrimonio ni del poder paterno, sino que estos elementos, a pesar de su importancia, descansan bajo la tutela de la moral y no bajo la protección del derecho"17.

Ahora bien, no compartimos la postura recién expuesta, ya que estimamos que no es clara con la determinación de la naturaleza jurídica de los deberes conyugales dentro de nuestro ordenamiento jurídico. Así pues, hasta el momento la doctrina y jurisprudencia señalada sostienen que los deberes conyugales son "deberes éticos-morales", o "deberes jurídicos restringidos" o con "cierta juridicidad", o incluso "obligaciones", pero que en cualquiera de estos casos, atendido su preeminencia moral y su imposibilidad de cumplimiento forzado frente a su infracción resulta imposible el ejercicio de la acción indemnizatoria.

Sobre el particular, lo que primero debemos tener presente es que si bien la controversia ha sido objeto de una ardua discusión, hoy en día, tanto en la doctrina comparada como nacional, tiene mayor acogida aquella que defiende el carácter jurídico de los deberes y derechos conyugales, siguiendo de esta forma a la Escuela Exegética francesa, inspirada en el Código Civil francés, que promovió la tesis de que éstos son "auténticos deberes jurídicos exigibles legalmente". Así pues, el Code Civil francés, al igual que el derecho español ${ }^{18}$ e italiano ${ }^{19}$, y como siempre desde 1804, recoge en sus artículos $212^{20}$ y $215^{21}$, los mutuos deberes y derechos de fidelidad, socorro y asistencia, y de comunidad de vida de los cónyuges, reconociéndolos como auténticos deberes jurídicos recíprocos, como "reglas de orden público que constituyen la base de la familia", exclusivamente matrimonial, y con una importante connotación

\footnotetext{
${ }^{16}$ LaCruz et al. (1990), p. 134.

17 SAVIGny (1878), p. 234.

${ }_{18}$ Véase, entre otros, a Alonso (1992), p. 50; LaCRuz, et al. (1990), p. 134; SANCHO (2001), p. 81 y ss.; Llamas (2007), p. 3 y ss.

19 Fraccon (2001), p. 988 y ss.; Bona (2003), p. 437 y ss.; De Verda (2007); Bona (2003), p. 398 y ss.
}

Plantea sus dudas sobre el carácter jurídico de los deberes conyugales Dogııotтı (1982), p. 130 y ss.

Por su parte ZATTI (1982), p. 7 y ss., sostiene que la juridicidad del "deber" emanada del matrimonio se sustituyó por una juridicidad de "mandamientos" planteados sobre el esquema del deber negativo, con el efecto -en parte adecuado a la disciplina en vigor- de delimitar la relevancia jurídica de la relación entre los cónyuges.

${ }^{20}$ Artículo 212 Cc. francés: "Los cónyuges se deben mutuamente fidelidad, socorro y asistencia".

21 Artículo 215 Cc. francés: "Los cónyuges se obligan mutuamente a una comunidad de vida. La residencia de la familia estará en el lugar que ellos escojan de común acuerdo...". 
moral, como se aprecia en que el legislador prefiera hablar de deber antes que obligación ${ }^{22}$.

Que en este sentido, podemos agregar que su carácter ético o moral no le priva de su juridicidad y, viceversa, su carácter jurídico no le priva de ser considerado también como un deber moral o ético.

Todas estas consideraciones Ilevan a que en el ordenamiento nacional, la doctrina dominante se inclina por entenderlos como verdaderos deberes jurídicos, no sólo por su consagración expresa en el texto legal sustantivo, sino que por ser necesarios para la obtención de los fines que el artículo 102 del Código Civil establece al matrimonio; sobre el particular, ilustrativas son las palabras de Barrientos Grandon y Novales Alquézar ${ }^{23}$ al afirmar-como en su oportunidad lo hizo Claro Solar ${ }^{24}-$, que "por el carácter de fin que asume el bien de los cónyuges, este fin se constituye en la causa que configura y justifica el nacimiento de una serie de recíprocos derechos y deberes entre los cónyuges, que aparecen como ciertos "efectos" del matrimonio jurídicamente considerados en cuanto se tienen por complementarios para la realización plena y efectiva de sus mismos fines, y que acostumbra explicarse bajo la rúbrica de "relaciones personales entre los cónyuges".

De la misma forma se manifiesta Larroucau García ${ }^{25}$, al criticar precisamente este argumento invocado por la Corte de Apelaciones de Santiago, ya que defiende que "el derecho de familia, a pesar de sus matices y de que en él necesariamente ciertos principios deban ser aplicados de modo diverso a lo que ocurre en el ámbito del derecho patrimonial, se encuentra conformado al igual

\footnotetext{
22 BénABEnt (1988), p. 117 y ss.; este autor, al estudiar la fidelidad, reitera que, tradicionalmente, este deber es de orden público, por cuanto los cónyuges no pueden alterarlo mediante un "pacto de libertad", ya que cualquier autorización en sentido contrario, se podría mirar como una injuria a su respeto, al igual que debería ser estimado inmoral todo pacto que induzca al adulterio; en el mismo sentido pueden verse los comentarios de HAUSER (1999), pp. 817 y ss., y en HAUSER (2005), p. 104 y ss., al expresar en esta última "obligation de fidelité, obligation d'ordre public, position approuvée par une part importante de la doctrine et difficilement contestable dans son principe".
}

También puede consultarse a BOUlanger (1990), p. 255 y ss.; CORNu (2001), p. 52 y ss., quién al tratar los deberes de comunidad de vida y fidelidad, también expresa que se trata de deberes "d'ordre public".

23 Barrientos y AránZazu (2004), p. 281.

${ }^{24}$ Claro (1978), p. 18, quien al hablar sobre los principios generales de los deberes comunes de los dos cónyuges, señalaba que "siendo el matrimonio un contrato en que un hombre y una mujer se unen con el fin de vivir juntos, de procrear y de auxiliarse mutuamente (art. 102), debía engendrar obligaciones civiles perfectas y no solamente deberes morales cuyo cumplimiento quedara abandonado a los escrúpulos de la conciencia privada".

25 Larroucau (2010b), p. 205 y ss.; Larroucau (2010a), p. 118. En el mismo sentido se manifiesta RodríGuez Pinto (2012). 
que éste de obligaciones no meramente morales y éticas, sino que estrictamente jurídicas cuya infracción debiera hacer procedente la indemnización de los perjuicios derivados de ese incumplimiento"; de esta forma, critica la sentencia referida, agregando que "lo que la Corte no puede hacer, basada en la idea de que las obligaciones emanadas del derecho de familia son éticas o morales, es dejar a una persona, que efectivamente ha sufrido un daño, sin ningún tipo de reparación, pues con semejante declaración reconoce el tribunal que existen en nuestro sistema jurídico ciertos daños que no se indemnizan, e impone injustamente al sujeto dañado una carga adicional de tener que soportarlo".

Que reafirma lo anterior, el hecho que el legislador nacional dispusiera determinadas consecuencias por su incumplimiento, tales como: a) incapacidad para contraer matrimonio ${ }^{26}$; b) causa de nulidad matrimonia ${ }^{27}$; c) causa genérica o general de separación judicial ${ }^{28}$; d) causa general de divorcio-sanción o por culpa de uno de los cónyuges ${ }^{29}$.

Sobre el particular, resultan oportunas las palabras del propio Alessandri Rodríguez $z^{30}$, quien al tratar los efectos del matrimonio entre los cónyuges expresamente indica que "el matrimonio, según el art. 102 del C.C., es un contrato, y como tal no crea para los cónyuges simples deberes morales, sino verdaderas obligaciones civiles cuya infracción está sancionada por la ley".

En fin, la comprensión de los deberes y derechos conyugales en todos estos ámbitos, entre otros, unidos a la importancia que revisten para la consecución de los fines que el Código Civil chileno expresa sobre el matrimonio, justifican sobradamente la posición mayoritaria que sobre este punto mantiene la doctrina y jurisprudencia nacional y comparada, y que los entiende como verdaderos deberes y derechos jurídicos, opinión mayoritaria que fue la que expresamente se reconoció por la Corte de Apelaciones de Talca con fecha 30 de agosto de

\footnotetext{
${ }^{26}$ Art. $5^{\circ} \mathrm{N}^{\circ} 4$ Ley de Matrimonio Civil.

27 Art. 44 letra a) Ley de Matrimonio Civil.

${ }^{28}$ Art. 26 Ley de Matrimonio Civil. Entre los efectos que se prevén como consecuencia de la resolución que declara la separación por culpa de uno de los cónyuges (se debe solicitar al juez que efectúe esta declaración en forma expresa en la sentencia y dejar constancia de ello en la subinscripción matrimonial respectiva), se hallan que el cónyuge culpable: a) pierda el derecho a suceder al otro (arts. 994 y 1182 Cc.); b) en materia de alimentos, sólo tenga derecho a una modesta sustentación (art. 175 Cc.); c) pierda el beneficio de competencia (art. 1625, en relación con el art. $1626 \mathrm{~N}^{\circ} 2 \mathrm{Cc}$.); d) se le revoquen las donaciones ( arts. 172 y 1790 Cc.); e) en el caso de existir régimen de sociedad conyugal, la mujer puede solicitar se declare la separación judicial de bienes en contra de su marido (art. 155 inc. $2^{\circ}$ Cc.). Sobre esta materia, pueden consultarse las obras de GarCía (2005), p. 526 y ss.; VéLIz (2004), p. 44 y ss.; Court (2004), p. 48 y ss.; Barrientos y Aránzazu (2004), p. 285 y ss.

29 Art. 54 Ley de Matrimonio Civil.

30 Alessandri (1941), p. 45.
} 
$2012^{31}$, quien conoció de una demanda de indemnización de perjuicios por daños materiales y morales interpuesta por la mujer en contra de su marido, fundada en la responsabilidad civil extracontractual como consecuencia de haberla contagiado del virus del papiloma humano producto de sus repetidas infidelidades matrimoniales, lo cual la llevó finalmente a someterse a una histerectomía total, truncando su vida a los cuarenta y tres años de edad; en este sentido el tribunal de segunda instancia fue claro al decir que los deberes conyugales, pese a que sean incoercibles directamente, son "auténticos deberes jurídicos exigibles legalmente"; agregan, siguiendo a la doctrina española, que "en este sentido, reconocen que se tratan de deberes jurídicos incoercibles directamente, pero agregan que ello no les priva de su juridicidad, sino que al contrario, hace tanto más urgente arbitrar los medios precisos para mantenerlos en pie en esta condición suya plenamente jurídica..., el carácter jurídico de los deberes conyugales debería hoy estar fuera de discusión, si pretendemos mantener el matrimonio con su naturaleza de institución jurídica" (considerando décimo), contradiciendo expresamente la posición adoptada por la Corte de Apelaciones de Santiago.

Ahora bien, aclarado que estamos frente a verdaderos deberes jurídicos, creemos que su incumplimiento sí da origen a la acción de indemnización de perjuicios en la medida que por ello se haya causado un daño, pese a que sean deberes jurídicos con fuerte contenido moral, y aunque no sea posible perseguir su cumplimiento forzadamente.

En este sentido se debe recordar, según ya hemos expuesto, que fundado en el contenido ético moral de los deberes conyugales como en su imposibilidad de ejecución forzada, Abeliuk Manasevich sostiene que éstos son deberes específicos que frente a su infracción no dan lugar a reparación, a diferencia de lo que acontece con el incumplimiento del deber general de conducta, como el de una obligación; no obstante, el citado autor, se olvida que tanto el deber general de conducta como la obligación también tienen un contenido moral, como por ejemplo se constata con el deber general de no causar daño a otro, o el no matar, los cuales tienen un claro contenido moral, y no por eso se les priva de su juridicidad ni se les niega la acción resarcitoria en caso de incumplimiento.

De la misma forma, Abeliuk Manasevich agrega como fundamento para rechazar la acción resarcitoria al ámbito que nos convoca, la imposibilidad de perseguir compulsivamente el cumplimiento de este deber, es decir, en la falta de acción para demandar el cumplimiento forzado de los deberes con-

31 Causa rol corte $N^{0} 133-2012$. Se debe agregar que contra esta sentencia se interpuso recurso de casación en el fondo el que fue desestimado por la Corte Suprema con fecha 2 de junio de 2013, causa rol corte $\mathrm{N}^{\circ} 7655-2012$. 
yugales; sin embargo, el citado autor se olvida que existen obligaciones en las cuales tampoco es posible perseguir su cumplimiento forzadamente y nadie discute ni niega su carácter obligacional o le niega la posibilidad de demandar la acción de indemnización de perjuicios frente a su incumplimiento, así por ejemplo se observa en todas las obligaciones de hacer intuito personae, donde la persona del deudor ha sido relevante para contratar, como sucede en el contrato de mandato respecto de las obligaciones del mandante (art. 2159 Cc.) y mandatario (arts. 2161 y 2167 Cc. cuando el incumplimiento es parcial, y arts. $2163 \mathrm{~N}^{\circ} 3,2165$ y 2156 cuando el incumplimiento es total); o en el contrato de arrendamiento para la confección de una obra material en lo concerniente a las obligaciones del artífice (art. 2005 Cc.); o en el contrato de sociedad de personas, cuando uno de los socios efectúa un aporte en industria (art. 2083 y 2103 Cc.). En todos estos casos, como se observa, la imposibilidad de perseguir el cumplimiento forzadamente se produce desde el inicio de la obligación, haciendo improcedente desde dicho instante cualquier demanda de cumplimiento por equivalencia, pero este hecho no niega ni impide el ejercicio de la acción indemnizatoria, como contrariamente lo sostiene Hernández Paulsen para los deberes conyugales según hemos expuesto.

2.- En cuanto al argumento de la aplicación del principio de especialidad del Derecho de familia:

Un segundo argumento invocado para rechazar la aplicación de las normas de responsabilidad civil frente al daño causado por incumplimiento de los deberes conyugales se encuentra en el Ilamado principio de "especialidad" o "especificidad" del Derecho de familia, que sostiene que frente a la infracción de los deberes personales del matrimonio sólo se pueden aplicar exclusiva y excluyentemente los efectos especialmente previstos por el legislador, descartando la aplicación de otras consecuencias.

En el orden nacional, defienden este principio en la materia que nos ocupa Severín Fuster" ${ }^{32}$ y Veloso Valenzuela, esta última al decir, que "ni la doctrina ni la jurisprudencia nacional han dispuesto que la falta de cualquiera de estos deberes de lugar a la indemnización de perjuicios; lo que parece razonable, dada las especificidades de la unión conyugal"33. De la misma opinión participa Ramos Pazos ${ }^{34}$, quien al estudiar los deberes conyugales, determina las sanciones específicas que corresponden frente a la infracción de cada uno de los deberes conyugales, limitando los efectos a dichas consecuencias.

32 Severín (2008), p. 132-140.

33 Veloso (2011), p. 149.

34 Ramos (2007), p. 142 y ss. 
Ahora bien, es nuevamente Hernández Paulsen ${ }^{35}$ quien, junto con sostener este principio, desarrolla una mayor justificación del mismo, al decir que frente a la infracción de los deberes conyugales nuestro ordenamiento jurídico establece "una serie de consecuencias específicas", como son la separación judicial y el divorcio causal, sin que se haya establecido expresamente la posibilidad de una acción indemnizatoria. Que la afirmación precedente se corrobora especialmente, primero, con la inexistencia de una regla general que obligue a indemnizar en materia de familia, pese que para otras determinadas situaciones el legislador estableció expresamente la regla contraria, como por ejemplo cuando se produce infracción a ciertas reglas en materia de sociedad conyugal (arts. 1748,1768 y 1771 Cc.) o del régimen de participación en los gananciales (art. 1792-18 Cc.); segundo, con el hecho de que el legislador reconoció explícita y detalladamente determinados efectos patrimoniales sólo frente a la infracción de ciertos deberes conyugales, como sucede con el derecho de alimentos que es la contracara del deber de socorro, o con la violencia intrafamiliar que es la contracara del deber de respeto y protección; tercero, con que el legislador estableciera efectos que sólo reaccionan frente a una violación grave de los deberes y obligaciones que impone el matrimonio en la medida que torne intolerable la vida en común (artículos 26 y 54 de la Ley de Matrimonio Civil), o frente a una transgresión grave y reiterada de los deberes de convivencia, socorro y fidelidad propias del matrimonio, lo que demuestra que solo las infracciones de cierta envergadura son trascendentes para el derecho, y limitado a los efectos por él previstos; y con el artículo 132 inciso $1^{\circ}$ del Cc. que en el caso del adulterio, sólo "da origen a las sanciones que la ley prevé", y entre las cuales no se encuentra en ninguna parte la de indemnizar los perjuicios.

En el orden jurisprudencial, esta posición fue seguida en la citada sentencia de la Corte de Apelaciones de Santiago de 10 de noviembre de 2009, resolución que apoyándose en la opinión de los autores Arturo Alessandri y Roberto De Ruggiero, de la teoría moderna, y de la jurisprudencia, rechazó toda acción indemnizatoria por incumplimiento de los "derechos de familia", sosteniendo que frente a tal infracción sólo se pueden aplicar exclusiva y excluyentemente las sanciones expresamente previstas por el legislador, y entre las cuales no se comprenden las acciones resarcitorias, todo ello como consecuencia del principio de especialidad que regiría al derecho de familia, y el cual se encuentra inspirado en tres principios rectores, el orden público, la limitación de la autonomía privada, y el carácter intuito personae.

Lo anterior, queda muy claro en su considerando cuarto, al decir, "los derechos de familia, y esta es la opinión de la teoría moderna y los tribunales

35 Hernández (2014). 
aceptan, no pueden cumplirse forzadamente. Para su incumplimiento hay otras sanciones establecidas por la ley para cada caso particular"; mucho más claro y categórico resulta el considerando décimo noveno, donde se señala que "los diferentes ordenamientos jurídicos han tratado de mantener los conflictos matrimoniales dentro de cierto grado de discreción, por lo cual, los legisladores, anticipándose al conflicto, han precisado las consecuencias de la infracción, como en el caso de autos, al deber de fidelidad. Es decir, el derecho de familia por su especialidad, contempla sus propias sanciones, no siendo aplicable en consecuencia, las normas generales sobre responsabilidad civil y por ende no corresponde-en un caso como el de autos-solicitar ni mucho menos conceder la reparación del daño moral" ${ }^{\prime 36}$.

En síntesis, de los considerandos reproducidos, queda clara la postura seguida en esta sentencia, la que también fue replicada por la Corte de Apelaciones de Puerto Montt en su fallo de 20 de diciembre de $2010^{37}$, quien, pronunciándose sobre la causa como elemento del pacto por medio del cual la cónyuge indemnizó el daño moral causado a su marido por el ilícito de adulterio, señaló en su considerando décimo cuarto que "pretender una indemnización por daño moral por una presunta relación extramatrimonial de uno de los cónyuges, es contraria al orden público, ya que aún (sic) en el caso de ser comprobada estaríamos frente a lo que el artículo 132 del Código Civil considera una grave infracción al deber de fidelidad que impone el matrimonio lo que según el mismo artículo da origen a las sanciones que la ley prevé, entre las cuales por cierto, las normas de orden público que regulan el matrimonio, no ha considerado la indemnización por daños morales al otro cónyuge".

Esta postura argumentativa, seguida por la doctrina nacional y jurisprudencia citada, no es nueva en el orden comparado, ya que concuerda con la jurisprudencia y doctrina alemana, como con algunos autores españoles, y asimismo con la posición de su Tribunal Supremo, como se observa en su sentencia de 30 de julio de 1999. Así pues, defensores del principio de especialidad del Derecho de familia frente a los daños causados por los cónyuges entre sí por incumplimiento de los deberes conyugales es el ordenamiento civil alemán. Sobre el particular, Enneccerus, Kipp y Wolff ${ }^{38}$ señalan que el máximo Tribunal alemán comparte la opinión de rechazar cualquier aplicación de la acción de respon-

\footnotetext{
${ }^{36}$ Esta misma idea es repetida en el considerando vigésimo primero, al exponer que "el hecho que el adulterio siempre haya tenido una sanción especial, establecida por el legislador en consideración a la naturaleza de la institución del matrimonio, piedra fundamental del derecho de familia, no permite considerarlo fuente de responsabilidad extracontractual como lo pretende el demandante".

${ }^{37}$ Causa rol No 181-2010.

38 EnNeCCERUS, Kipp y Wolff (1953), p. 196.
} 
sabilidad prevista en el parágrafo $823^{39}$ BGB para este escenario, manteniendo con ello, la posición instaurada por los redactores de dicho texto sustantivo, en el sentido que los reclamos por las pérdidas sufridas por cualquiera de los cónyuges como consecuencia de la negligencia de las obligaciones maritales del otro, son incompatibles con la naturaleza del matrimonio, y que, de admitirlos, importaría una pena para el divorcio ${ }^{40}$; el máximo tribunal añade que sólo corresponde el recurso exclusivo y excluyente de los efectos y sanciones expresamente previstos en el Derecho de familia, descartando cualquier acción civil entre cónyuges, destinada a la reparación de los daños y perjuicios causados por incumplimiento ${ }^{41}$.

Por su parte, en el ordenamiento jurídico español, Ferrer Riba ${ }^{42}$, Albaladejo $^{43}$, Roca i Trías ${ }^{44}$ y Romero Coloma ${ }^{45}$, también defienden la aplicación exclusiva y excluyente de las medidas expresamente previstas por el legislador para el caso de infracción; según esta posición, el principal efecto radica en el hecho que, para el legislador, el incumplimiento de los deberes y derechos conyugales es constitutivo de causa de separación y divorcio, medida suficientemente eficaz que destierra cualquier recurso a las normas de responsabilidad civil por los daños que se pudieran ocasionar. Ahora bien, la jurisprudencia española es quien con mayor insistencia ha seguido esta argumentación como se observa en la sentencia de su Tribunal Supremo de 30 de julio de $1999^{46}$, ya que, precisamente amparada en el principio de especialidad de las sanciones del Derecho de familia, rechazó la aplicación de las normas de responsabilidad civil frente a los daños causados a cualquiera de los cónyuges por incumplimiento de los deberes conyugales vigente el matrimonio. En efecto, en esta

39 Parágrafo 823 BGB: "Obligación de indemnizar por daños. 1. Quien, dolosa o negligentemente, de forma antijurídica dañe la vida, el cuerpo, la salud, la libertad, la propiedad u otro derecho de otra persona, está obligado a indemnizarle cualquier daño causado por esto. 2. La misma obligación incumbe a aquel que infrinja una ley que tenga como objeto la protección de otro. Si, de acuerdo con las disposiciones de la ley, la infracción de ésta es posible sin culpa, la obligación de indemnizar sólo aparece en caso de culpa".

40 MARKESINIS (1994), p. 313.

41 Markesinis (1994), p. 60; RodríGuez Guitián (2003), p. 70.

42 Ferrer (2001), p. 14 y ss.; Ferrer (2003), p. 1854 y ss.

43 Albaladejo (2002), p. 119 y ss.

44 Roca (2000), p. 546 y ss.

45 Romero (2000), p. 544 y ss.

46 RJ 1999, 5726; en RC Revista de Responsabilidad Civil, Circulación y Seguro, noviembre 1999, p. 571 y ss.; en Auto del Tribunal Constitucional № 140/2001, de 4 de junio (RTC 2001, 140 auto); véase también comentarios a la sentencia en SANCHO (2001), p. 77 y ss.; ROMERO (2000), p. 544 y ss.; RAGel (2000a), pp. 153-163. 
sentencia (y quizá la más clara en España sobre el tema que nos ocupa), el Tribunal Supremo, conociendo del recurso de casación interpuesto por el actor, por medio del cual pretendía de su cónyuge el resarcimiento de daños morales por el ocultamiento doloso de la verdadera paternidad de dos supuestos hijos matrimoniales, fundado en la infracción de los deberes conyugales en relación con la responsabilidad civil contractual, resolvió que "indudablemente, el quebrantamiento de los deberes conyugales especificados en los artículos 67 y 68 del Código civil, son merecedores de un innegable reproche ético-social, reproche que, tal vez, se acentúe más en aquellos supuestos que afecten al deber de mutua fidelidad, en los que, asimismo, es indudable que la única consecuencia jurídica que contempla nuestra legislación sustantiva es la de estimar su ruptura como una de las causas de separación matrimonial en su artículo 82 pero sin asignarle, en contra del infractor, efectos económicos,... e, igualmente, no cabe comprender su exigibilidad dentro del precepto genérico del artículo 1101, por más que se estimen como contractuales tales deberes en razón de la propia naturaleza del matrimonio, pues lo contrario llevaría a estimar que cualquier causa de alteración de la convivencia matrimonial, obligaría a indemnizar". No obstante, cabe mencionar que con la ley № 15/2005, se consagró el divorcio abstracto o acausal restando valor a los fundamentos de esta posición al dejarlos sin su principal consecuencia frente a la infracción de los deberes conyugales, esto es, el divorcio, otorgando mayor valor aquella parte de la doctrina española que rechaza el principio de especialidad del Derecho de familia, y defiende la aplicación de las normas de responsabilidad civil frente a los daños causados por incumplimiento de los deberes conyugales, sosteniendo que "no vale alegar la presencia de unas limitadas sanciones específicas para castigar la infidelidad o el abandono (desheredación, causa de separación), o bien la idea general del legislador de prescindir de la declaración de culpabilidades en tema de divorcio o la eficacia de éstas en la separación, motivo que no es suficiente para suprimir la vigencia de las normas sobre daños y resarcimiento" ${ }^{\prime 4}$.

De la misma opinión se pronuncia mayoritariamente el derecho argentino según destaca Medina, al señalar que "vemos que se ha eliminado la idea de que en la familia no se reparan los daños causados entre sus integrantes y que se ha desechado completamente la concepción de que la especialidad del Derecho de Familia impide la aplicación de los principios de la responsabilidad civil"48, agregando que "el Derecho de Familia no constituye un ordenamiento que se

47 LACRUZ (1994), p. 663; LACRUZ et al. (1990), p. 143; en el mismo sentido se manifiesta Marín (2004).

48 Medina (2008), p. 21. 
baste a sí mismo, y por ende para solucionar los conflictos deben aplicarse los principios de la teoría general del Derecho Civil"49.

Y precisamente, atendidos estos últimos fundamentos expuestos, la Corte de Apelaciones de Talca en el fallo ya citado de 30 de agosto de 2012, se manifestó contraria al argumento de la especialidad defendido por la Corte de Apelaciones de Santiago, señalando en su considerando noveno que, en este sentido "no puede invocarse el argumento de la especificidad y carácter completo de las normas del Derecho de familia, para sostener que la infracción de los deberes conyugales hallan su propia y exclusiva sanción en las medidas típicas en ellas previstas, como son la separación y el divorcio, ya que la naturaleza, función y límites de estas medidas, hacen evidente que éstas no son incompatibles con la tutela de los derechos constitucionalmente garantizados, no pudiéndose excluir que un solo hecho pueda dar lugar a la separación o divorcio, y al mismo tiempo, pueda ser generador de responsabilidad aquiliana, si concurren los requisitos para ello".

En el mismo sentido de la Corte de Apelaciones de Talca, se manifiesta en el orden nacional, Valenzuela del Valle ${ }^{50}$ y Larroucau García ${ }^{51}$; esta última es clara al decir, que "tampoco puede sostenerse, como se ha hecho por nuestra doctrina, que los daños que se originen los cónyuges producto de la violación de las obligaciones maritales tiene como resarcimiento la propia declaración de divorcio y en consecuencia no sería procedente por inaceptable, la obtención de una doble reparación. Evidentemente, no puede considerarse al divorcio en sí una reparación de los eventuales daños sufridos por los cónyuges, ya que en definitiva el divorcio no es más que la aplicación del aforismo de que en el derecho las cosas se deshacen tal como se hacen". De la misma idea participa Novales Alquézar ${ }^{52}$ al criticar el alegado argumento de la especialidad del Derecho de Familia, ya que, "al menos extracontractual, debe admitirse en quien ocasiona el daño en la relación personal entre 'personas capaces', valga la redundancia, ya que el dañado tendrá derecho al resarcimiento si no como cónyuge, padre o abuelo, al menos, como persona".

Por último, y en apoyo de la postura que critica el principio de especialidad, y a la cual nos adherimos, agregamos que en el argumento del artículo 132 inciso $1^{\circ}$ del Código civil expuesto por Hernández Paulsen creemos se confunde la finalidad que, conforme la mayoría de la doctrina y jurisprudencia nacional,

\footnotetext{
49 Medina (2008), p. 51.

50 VAlenzuela (2012), p. 247.

51 Larroucau (2010a), p. 120.

52 Novales (2008), p. 135 y ss.
} 
tendría la acción indemnizatoria, que es la de reparar, resarcir el daño causado, pero no de una sanción frente a una infracción; así pues, cuando el legislador dispone que en el caso del adulterio "da origen a las sanciones que la ley prevé", sólo está limitando las sanciones que de dicho incumplimiento emanan, pero nada está diciendo acerca de la acción indemnizatoria a que pueda dar lugar, la que dependerá no sólo del hecho de haberse cometido el adulterio, sino que de dicha infracción se haya causado un daño, el que deberá ser indemnizado para cumplir así con la finalidad de esta acción.

3.- Que los principios del Derecho de familia impiden las acciones de responsabilidad:

Otro de los fundamentos esgrimidos en el citado fallo de la Corte de Apelaciones de Santiago para rechazar la acción de indemnización de perjuicios interpuesta por el ilícito civil de adulterio, dice relación con el hecho de que los principios sobre los cuales se estructura el Derecho de Familia, a saber, el que sus normas sean de orden público, en la limitación de la autonomía privada o autonomía de la voluntad, y su carácter intuito personae, lleva a que sus actos sean absolutamente distintos de los actos jurídicos patrimoniales; que estas diferencias justificarían el principio de especialidad, el carácter ético-moral de los deberes conyugales, y la exclusión de las normas sobre responsabilidad civil a los actos de familia, propios de los actos jurídicos patrimoniales. Así se desprende del considerando décimo cuarto, al decir "que, del análisis de los tres principios recién comentados -orden público, limitación de la autonomía privada o autonomía de la voluntad y, carácter intuito personae-, se puede concluir que, los actos de familia, no solo por su naturaleza sino que por sus particularidades se distinguen absolutamente de los actos jurídicos patrimoniales". Conforme a lo expuesto, los sentenciadores finalmente concluyen que "el hecho que el adulterio siempre haya tenido una sanción especial, establecida por el legislador en consideración a la naturaleza de la institución del matrimonio, piedra fundamental del derecho de familia, no permite considerarlo fuente de responsabilidad extracontractual como lo pretende el demandante, pues las normas que regulan tales materias se refieren a la reparación de daños derivados de obligaciones de carácter patrimonial, motivo por el cual no resulta jurídicamente procedente acoger la presente demanda" (considerando vigésimo primero).

De las ideas recién expuestas por la Corte de Apelaciones de Santiago, la de aquella que pone el acento en el carácter de orden público, como de la regla de especialidad que regiría el Derecho de Familia, fueron también seguidas por la Corte de Apelaciones de Puerto Montt, ya que precisamente apoyándose en estos fundamentos expuso que "existe objeto ilícito en todo pacto en que los cónyuges pretendieren obligarse unilateral o recíprocamente al pago de una indemnización por daño moral para el caso de faltar al deber de guardarse fe, 
por así disponerlo el artículo 1462 del Código Civil" (considerando decimoséptimo); en otras palabras, sostienen que es nulo un pacto de esta naturaleza y finalidad por adolecer de objeto ilícito, ilicitud que consistiría precisamente en ir contra las normas de orden público del Derecho de Familia, y que frente a la infracción de los deberes conyugales, sólo permitiría la aplicación de las consecuencias o efectos especialmente previstos por el legislador, entre los cuales no se encuentra la reparación del daño moral.

En este sentido, la Corte de Apelaciones de Puerto Montt entiende que si la causa que motivó el pacto por el cual se acordó entre los cónyuges el pago de una suma de dinero fue por incumplimiento del deber de fidelidad, la normativa aplicable al caso concreto serían las normas de responsabilidad civil contractual, ya que estamos frente al incumplimiento de una obligación contractual, y que "como la mayoría de la jurisprudencia y doctrina lo ha sostenido, en nuestro ordenamiento jurídico el daño moral en materia de incumplimiento contractual no es indemnizable, pues no existe en el Título XII del Libro Cuarto del Código Civil, una disposición como la del artículo 2329 del mismo Código para el caso de la responsabilidad extracontractual, de manera que debemos estarnos al artículo 1556 que limita la responsabilidad al daño emergente y lucro cesante" (considerando décimo tercero), de manera tal, que el pacto celebrado entre los cónyuges por el cual se indemnizó el daño moral carecería de "causa real". Sin embargo, sobre esta última afirmación nos limitamos a recordar que desde la sentencia de la Corte Suprema de 20 de octubre de 199453, la jurisprudencia y doctrina nacional de forma dominante se ha pronunciado en sentido favorable a la reparación del daño moral en sede contractual ${ }^{54}$.

Quien también compartió el fundamento de que las normas del Derecho de Familia son de orden público, como que el pacto por el cual los cónyuges acuerdan una indemnización por daño moral por infracción del deber de fidelidad adolece de objeto ilícito, fue la primera sala de la Corte Suprema, quien, en su fallo de 6 de marzo de $2012^{55}$, conociendo del recurso de casación en el fondo interpuesto contra la referida sentencia de Puerto Montt, señaló que si bien "el Derecho de Familia es una disciplina perteneciente al Derecho Privado, se reconoce que en él existen normas de Derecho Público que no pueden ser suprimidas o modificadas por los interesados"; el máximo Tribunal agregó,

\footnotetext{
53 Gaceta Jurídica № 174, 1994, p. 155.

${ }^{54}$ En este sentido, pueden verse las sentencias de la Corte de Apelaciones de Concepción de 19 de enero de 1990, en Gaceta Jurídica № 122, 1990, p. 31; Corte de Apelaciones de Santiago de 6 de agosto de 1996, en Gaceta Jurídica № 194, 1996, p. 70; Tomasello (1969); Jana y Tapia (2004), pp. 171-209; Pizarro (2007).

${ }_{55}$ Causa rol No $778-2011$.
} 
citando a Hernán Troncoso Larronde, que las peculiaridades del Derecho de Familia son "consistentes fundamentalmente en limitaciones importantes al principio de autonomía de la voluntad y en la ampliación sistemática y notable del orden público en su normas"; en virtud de estos fundamentos, concluyeron en definitiva, que la obligación que supone el pago de una suma de dinero entre cónyuges como indemnización por daño moral por infracción del deber de fidelidad "tiene por fundamento un objeto ilícito pues contrarían el Derecho Público Chileno, como lo determina el artículo 1462 del Código Civil" (considerandos décimo quinto y décimo sexto ${ }^{56}$.

Ahora bien, creemos oportuno hacernos cargo de estos fundamentos para determinar si realmente los principios del Derecho de Familia, en específico la restringida autonomía de la voluntad y el orden público, constituyen un impedimento a la aplicación de las normas de responsabilidad civil.

Frente a la interrogante planteada, debemos aclarar que siguiendo a DíezPicazo y Ponce de León ${ }^{57}$, si bien reconocemos que el Derecho de Familia presenta principios y características que lo distinguen del Derecho patrimonial, éste sigue siendo parte del Derecho privado, y el rol que tiene la autonomía privada o autonomía de la voluntad es el mismo en ambos derechos.

Así pues, tanto en el Derecho de familia como en el Derecho patrimonial, sus actos nacen por la intervención que en ellos ha tenido la autonomía privada, con independencia de que sus efectos sean consecuencia de la voluntad o de la ley, y esto es lo que caracteriza a los actos jurídicos en general, sean familiares o patrimoniales, la intervención de la autonomía de la voluntad en la creación del acto. En este sentido, para calificar a un acto como jurídico no se debe atender a si sus efectos derivan exclusivamente o no de la voluntad de las partes, ya que desde este punto de vista, "la voluntad de los particulares no es, ni puede ser nunca por sí sola, causa de efectos jurídicos. La causa de un efecto jurídico sólo puede ser, en rigor, una norma, un precepto. Para que de una declaración de voluntad deriven efectos jurídicos es menester que el derecho objetivo reconozca o atribuya esta virtud a la voluntad privada, por donde el efecto tanto deriva de la ley como de la voluntad"; desde este punto de vista, tampoco existen efectos según la ley, toda vez que éstos tampoco se producen "sin la realización voluntaria del acto jurídico, de suerte que el efecto tanto deriva de la voluntad como de la ley"58.

\footnotetext{
56 Sin embargo, hacemos presente, que los fundamentos expresados en estos considerandos, no fueron compartidos por el ministro suplente don Carlos Cerda Fernández.

57 Díez (1962), pp. 771-792.

58 Dí́zZ (1962), p. 777-778.
} 
Dicho lo anterior, queda claro que el principio de la autonomía de la voluntad tiene la misma trascendencia tanto en el Derecho de familia, como en el Derecho patrimonial, más aún en la actualidad, en el cual se reconoce que este principio ha tenido una progresiva extensión en virtud de las modificaciones que se han introducido en esta materia (por ejemplo, la mutabilidad de los regímenes patrimoniales, los acuerdos en materia de cuidado personal de los hijos y la patria potestad en especial después de la ley $N^{\circ} 20.680$ de 21 de junio de 2013, el acuerdo completo y suficiente en los casos de separación o divorcio, entre otros); en virtud de lo anterior, Domínguez Hidalgo ${ }^{59}$ señala que "tradicionalmente se ha afirmado que una gran diferencia entre el Derecho patrimonial y el Derecho de Familia es el ámbito de extensión de la autonomía de la voluntad afirmándose que ese principio básico del Derecho privado recibiría plena e ilimitada vigencia en el ámbito patrimonial, no así en materia de familia donde solo existiría la libertad para celebrar o no un acto pero una vez ejercida la opción en orden a ejecutarlo los particulares se encontrarían obligados a someterse al estatuto legalmente impuesto, inderogable para ellas. En el presente, no obstante, habida cuenta de las reformas referidas, lo cierto es que ese tipo de afirmación merece ser reformulada o, por lo menos, matizada... La autonomía de la voluntad como ejercicio de la libertad individual ha alcanzado en este ámbito una extensión antes impensable. Como se suele afirmar el Derecho de Familia tiende paulatinamente a contractualizarse en un fenómeno exactamente inverso al que se produce en el Derecho de los contratos que tiende progresivamente a reconocer más límites a la libertad contractual".

Expuestas las circunstancias señaladas, no cabe duda que hoy en día el Derecho de familia se ha desarrollado, abriendo su carácter privatista, contractualista, donde se observa la primacía de la decisión unilateral e interés individual de la persona, Ilevando a que "el principio de libertad del individuo tiende a formularse sin referencia alguna a la familia y, por lo mismo, a desprenderse de algunas de las trabas que el orden público envuelto en ella le imponen" ${ }^{60}$.

Esto lleva a que los límites del Derecho de familia, que son los mismos para todo el Derecho privado -la ley, la moral y el orden público-, se reformulen conforme a esta nueva visión de la familia.

En este sentido, se debe tener presente que el orden público no es más que "el conjunto de normas y principios jurídicos que tienden a resguardar primordialmente los intereses generales de una sociedad determinada en un

59 Domínguez (2005a), p. 212.

${ }^{60}$ Domínguez (2005a), p. 213. 
momento histórico de su existencia" ${ }^{\prime \prime 1}$, y conforme al momento actual de la sociedad chilena, la familia no es un campo que esté limitada por un principio de especialidad, que establezca un campo de inmunidad donde sus miembros se puedan recíprocamente dañar, o donde sus integrantes deban sacrificar sus intereses individuales por sobre un interés suprafamiliar; la familia ha cambiado, centrándose más en los individuos que la componen más que en la entidad familiar misma; los derechos e intereses de la familia se han desplazado por el reforzamiento de los derechos individuales de los miembros de la familia, lo cual es consecuencia del hecho de que hoy en día, la primera protección del Estado es la persona, sus derechos fundamentales, sus derechos subjetivos, y la familia el instrumento que permite el desarrollo de ella.

De la misma opinión participan Dutto ${ }^{62}$ y Medina para el Derecho argentino, afirmando esta última que "en la actualidad, la evolución del Derecho de Familia ha conducido a privilegiar la personalidad y autonomía del sujeto familiar respecto de la existencia de un grupo organizado en sentido jerárquico. El sujeto familiar es, por sobre todas las cosas, una persona, y no existe ninguna prerrogativa familiar que permita que un miembro de la familia cause daño dolosa o culposamente a otro y se exima de responder en virtud del vínculo familiar" ${ }^{\prime 63}$.

La nueva tendencia considera a la familia como un instrumento al servicio de sus miembros, los cuales amparados en un plano de igualdad, alcanzan sus fines individuales, desapareciendo con ello, toda idea de unidad familiar, o de célula de la sociedad estatal; la familia es ahora el medio de desarrollo de los derechos de la persona.

Como afirma Finocchiaro ${ }^{64}$, "si no hay duda de que la familia es una de las formaciones sociales donde el individuo desarrolla su propia personalidad, es igualmente claro que los derechos reconocidos y tutelados por la ley son los propios del hombre, y que las formaciones sociales -por ejemplo, la familia- en tanto vienen constitucionalmente garantizadas en cuanto en ellas el individuo puede enriquecer su propia personalidad. Por tanto, en el ámbito de la familia, bajo el aspecto jurídico, no existen intereses que trasciendan los intereses indi-

\footnotetext{
${ }_{61}$ Vodanovic (1961), p. 159. En el mismo sentido, Rodríguez Grez (2012), p. 236, que define al orden público como "el conjunto de normas y principios que en un momento histórico determinado, por representar las bases del orden social establecido, deben ser impuestos aun contra la voluntad de las personas, sean ellas particulares o constituidas en autoridad".

${ }^{62}$ Dutto (2007), p. 30.

${ }^{63}$ Medina (2008), p. 21.

${ }^{64}$ Citado por Reina y Martinell (1995), p. 18.
} 
viduales de los distintos componentes de la misma; no existe un interés superior familiar, sino el interés de un cónyuge respecto del otro para el cumplimiento de las obligaciones recíprocas impuestas por la ley, y el interés de los padres al sostenimiento, educación e instrucción de los hijos, así como el interés de estos últimos en ser sustentados, educados e instruidos. En el seno de la familia tales intereses son coordinados y atemperados, pero no porque exista un fin superior, sino con la finalidad de propiciar una pacífica y fructífera convivencia para el bien de cada uno de los que conviven".

En este sentido, si bien la Constitución chilena señala que "la familia es el núcleo fundamental de la sociedad" (art. $1^{\circ}$ inc. $\left.2^{\circ}\right)$, no se debe olvidar que la misma Carta Fundamental consagra que "las personas nacen libres e iguales en dignidad y derechos" (art. $1^{\circ}$ inc. $1^{\circ}$ ), dignidad y derechos que las personas no renuncian por el hecho de pertenecer a una familia, o por el matrimonio, y entre cuyos derechos se asegura a todas las personas su "derecho a la vida y a la integridad física y psíquica" (art. $19 \mathrm{~N}^{\circ} 1^{\circ}$ inc. $1^{\circ}$ ), como de su "hon$r a^{\prime \prime}$ (art. $19 \mathrm{~N}^{\circ} 4^{\circ}$ ), integridad y honra que obliga a reparar los daños que se causen a éstas ya sea dentro de la familia o fuera de ella, ya que "el Estado está al servicio de la persona humana... para lo cual debe contribuir a crear las condiciones sociales que permitan a todos y cada uno de los integrantes de la comunidad nacional su mayor realización espiritual y material posible, con pleno respeto a los derechos y garantías" que la Constitución establece (art. $1^{\circ}$ inc. $4^{\circ}$ ).

\section{De la resarcibilidad de los daños entre cónyuges}

Expuestos los argumentos de aquellos que sostienen la irresarcibilidad de los daños entre cónyuges por incumplimiento de los deberes conyugales, como nuestra crítica respecto de cada uno de ellos, lo que queda por aclarar para cumplir con el objetivo planteado en el título de este trabajo, es revisar nuestro Código Civil, la Ley de Matrimonio Civil, y el resto del ordenamiento jurídico nacional, hecho que nos permite constatar que no existe ninguna regla general que se refiera a la situación de los daños causados entre los cónyuges vigentes la unión conyugal, ya sea para excluir, modificar, la aplicación de las normas de responsabilidad a esta materia. Si bien, existen algunas normas particulares en nuestro texto sustantivo concernientes a ciertas responsabilidades que regulan situaciones especiales en el ámbito del Derecho de familia, a saber, el artículo 98 que regula la situación en materia de esponsales, el artículo 130 que establece la responsabilidad solidaria de la mujer y su nuevo marido por la incertidumbre y confusión de paternidad, el artículo 141 relativa a la acción fraudulenta de uno de los cónyuges para obtener la declaración de bien familiar, el artículo 197 concerniente a las acciones de filiación de mala fe o destinadas 
a la lesionar la honra del demandado, el artículo 328 que prevé la situación de aquel o aquellos que con dolo obtuvieron alimentos, el artículo 1748 que regula el caso del cónyuge que con dolo o culpa grave ocasiona perjuicios a la sociedad conyugal; como se aprecia, se trata de situaciones especiales, que en ningún caso consagran una regla que regule en términos generales o particulares los daños causados entre cónyuges por incumplimiento de los deberes conyugales.

Frente a este escenario, somos partidarios de recurrir a las reglas generales en materia de responsabilidad, entiéndase sus arts. 1545 y ss. y 2314 y ss., y que obligan a todo autor de un ilícito civil, ya sea contractual o extracontractual, del cual se cause daño, a su íntegra reparación. En este sentido, somos de la opinión que sí son resarcibles los daños causados en el matrimonio por los cónyuges entre sí, ya que, como hemos dicho, no existe ninguna norma que prohíba, excluya o restrinja la aplicación de las normas de responsabilidad civil. Es más, precisamos que somos partidarios de aplicar el estatuto de responsabilidad civil siempre que por incumplimiento de un deber conyugal se cause un daño al otro cónyuge, al igual como lo expresó la Corte de Apelaciones de Talca, al decir en su considerando octavo ya citado, que "seguimos a la doctrina comparada que sobre el particular se inclina mayoritariamente por la posibilidad de indemnizar los daños y perjuicios que se produzcan por el incumplimiento de los deberes matrimoniales. No se vislumbra ninguna buena razón para impedir, a priori, una posible indemnización por el incumplimiento de los deberes matrimoniales". En este sentido, existiendo un daño o perjuicio causado por el incumplimiento de un deber conyugal se deben aplicar las normas de responsabilidad civil, a las cuales precisamente les atribuimos una finalidad resarcitoria, compensatoria o satisfactoria según sea la naturaleza del daño.

Nuestra posición no sólo se fundamenta en el hecho de que no compartimos los fundamentos de aquellos que sostienen la irresarcibilidad de los daños entre cónyuges ya expuestos, sino que por sobre todo creemos en la existencia de un principio general de responsabilidad que inunda todo nuestro ordenamiento jurídico, incluido el Derecho de familia en general y el matrimonial en lo particular, en la medida que concurran los requisitos para ello, y no estemos frente a un escenario especialmente excluido o restringido de dicha aplicación (como acontece en el caso de los esponsales). En este sentido, al entender los deberes personales del matrimonio como deberes jurídicos, resulta lógico defender que de si su incumplimiento se cause un daño a uno de los cónyuges, éste tenga derecho a la reparación.

Creemos que la afirmación anterior, además, es la tendencia mayoritaria de la escasa doctrina nacional que se ha pronunciado sobre el particular, como es 
Larroucau García ${ }^{65}$, Rodríguez Pinto ${ }^{66}$, Corral Talciani ${ }^{67}$, Herane Vives ${ }^{68}$, Domínguez Hidalgo ${ }^{69}$, Vidal Olivares ${ }^{70}$, Barrientos Grandon y Novales Alquézar ${ }^{71}$, y Valenzuela del Valle ${ }^{72}$, quienes se manifiestan en términos generales por la procedencia de la indemnización por aplicación de las normas de responsabilidad civil frente a los daños causados por incumplimiento de los deberes conyugales.

En el mismo sentido, no podemos dejar de mencionar al profesor Somarriva Undurraga ${ }^{73}$, quien, años atrás, precisamente al hablar de los efectos por el incumplimiento del deber de fidelidad, ya señalaba que la "jurisprudencia francesa concede también al cónyuge inocente el derecho de reclamar una indemnización de perjuicios del cónyuge culpable", agregando que "nuestros tribunales no se han pronunciado sobre el particular, pero bien podrían adoptar igual temperamento, dada la amplitud de la responsabilidad extracontractual y la aceptación unánime que recibe la procedencia de la indemnización del daño moral", lo que demuestra que para el citado autor, habiéndose causado un daño, incluido el moral, por el incumplimiento de un deber conyugal, bien podría tener lugar la acción de indemnización de perjuicios.

Esta nueva concepción que se abre en la doctrina nacional, se extiende incluso a los mismos defensores de la irresarcibilidad, quienes, bajo determinados supuestos, dan cabida al resarcimiento entre cónyuges, aunque sea desvinculándose de los daños causados por incumplimiento de los deberes conyugales, como en los casos de perpetración de un delito o falta, o la infracción de derechos fundamentales, o la violación del principio general de no causar daño a otro. En otras palabras, esta posición niega la reparación de los daños causados por incumplimiento de los deberes conyugales, pero admite la reparación de los daños entre cónyuges cuando éste tiene su origen en un delito o falta, o la infracción de un derecho fundamental, o la infracción del deber general de no causar daño a otro, ya provenga el delito o falta o infracción del incumplimiento o no de un deber conyugal. Así se manifiesta Hernández Paulsen ${ }^{74}$, quien,

\footnotetext{
${ }^{65}$ Larroucau (2010b), p. 205; y Larroucau (2010a), pp. 115 y ss.

66 Rodríguez Pinto (2012).

${ }^{67}$ Corral (2008), pp. 88 y ss.

${ }^{68}$ Herane (2006), pp. 189 y ss.

${ }^{69}$ Domínguez (2005b), p. 27.

${ }^{70}$ VIDAL (2004), p. 287.

71 Barrientos y AránZazu (2004), pp. 409-410.

72 Valenzuela (2012), pp. 241-269.

73 Somarriva (1983), pp. 134 y ss.

74 HeRnÁNDEZ (2014).
} 
como ya hemos señalado, es contrario a la reparación de los daños causados por incumplimiento de los deberes conyugales, salvo que "el respectivo detrimento fluya de la vulneración de intereses jurídicamente relevantes y que no provengan de una infracción de los denominados "deberes conyugales", lo cual ocurrirá en caso de que la respectiva conducta sea constitutiva de delito o falta penal, atente contra derechos fundamentales de la víctima o implique una vulneración del deber general de no dañar, siempre que, por supuesto, se reúnan todos los requisitos de la responsabilidad civil..., tanto si el respectivo menoscabo implica un atropello de un interés perteneciente claramente a la órbita de la vida familiar o del Derecho de familia como si no".

En similares términos se pronuncia Severín Fuster $^{75}$, ya que si bien rechaza la indemnización de los daños por incumplimiento de los deberes conyugales, defendiendo que frente a estas infracciones se deben aplicar los remedios específicos, especialmente determinados por el Derecho de familia, agrega que esto no significa que en el ámbito matrimonial exista inmunidad para que los cónyuges se puedan dañar, ya que "cuando exista un daño a un derecho o interés conceptualmente distinto del mero interés en conservar el matrimonio o en el cumplimiento de los deberes personales", sí serían aplicables las reglas de la responsabilidad, es decir, corresponderían las acciones de resarcimiento cuando el daño no sea consecuencia del incumplimiento de los deberes conyugales, sino que de un derecho o interés desvinculado de la existencia del matrimonio. Ahora bien, agrega, que nada impide que este daño indemnizable pueda tener su causa con ocasión del incumplimiento de un deber conyugal, o con ocasión de la ejecución de otras conductas que ni siquiera sean infracción a éstos; que lo importante sería distinguir el daño causado por incumplimiento del deber conyugal que no sería indemnizable, del daño a un derecho o interés distinto o desvinculado del vínculo matrimonial que sí sería indemnizable, aunque haya tenido su fuente con ocasión del incumplimiento de un deber conyugal ${ }^{76}$.

Esta última posición parece ser la seguida por la Corte de Apelaciones de La Serena, en su sentencia dictada con fecha 3 de abril de $2014^{77}$, quien conociendo

\footnotetext{
75 SeVerín (2008), p. 132-140.

76 De esta misma opinión participan en la doctrina española ROCA (2000), p. 561 y ss.; FeRRER (2001), p. 15; Ferrer (2003), p. 1857; RodríGuez Guitián (2003), p. 73; quienes pese a defender la irresarcibilidad de los daños causados entre cónyuges por incumplimiento de los deberes conyugales, sostienen expresamente lo contrario cuando ese daño es consecuencia de un hecho constitutivo de delito o falta previsto en el Código Penal, o lesión de un derecho fundamental (de esta opinión excluimos a Roca i Trías), ya con ocasión o no del incumplimiento de un deber conyugal. En el ordenamiento italiano, esta misma postura es seguida por Bona (2003), p. 412.

77 Causa rol No 507-2013. Se hace presente que a la fecha de redacción de este trabajo, se encuentra pendiente ante la Corte Suprema el recurso de casación en el fondo interpuesto por el demandado.
} 
de un recurso de apelación interpuesto en contra de la resolución que acogió la acción indemnizatoria presentada por la mujer en contra de su excónyuge después de haber obtenido a su favor el divorcio por culpa, confirmó la sentencia de primer grado, señalando que si bien es discutible que la indemnización de perjuicios en el ámbito matrimonial sea aplicable para todas las causales de divorcio por culpa contempladas en el artículo 54 de la Ley de Matrimonio Civil, ya que "habría que analizar el caso concreto, con todas sus circunstancias", de lo que "no existe duda alguna, es que tal indemnización resulta del todo procedente cuando el motivo que dé lugar al divorcio afecta a la persona del otro cónyuge, independientemente si estaban o no unidos por el lazo matrimonial, como lo es, el atentado contra la vida o malos tratamientos graves contra la integridad física o psíquica del cónyuge víctima, cuyo es el caso de autos" (considerando décimo cuarto). Es decir, el tribunal de segunda instancia, para confirmar la sentencia de primer grado que acogió la acción indemnizatoria interpuesta por la mujer, lo hizo poniendo el acento en los daños causados por la lesión de derechos fundamentales más que en la existencia del vínculo matrimonial que existió entre víctima y victimario, aunque advertimos que en los considerandos décimo quinto al décimo noveno, el sentenciador si tuvo en cuenta la existencia de los hechos que dieron origen al divorcio por culpa, y con ello, el incumplimiento grave de los deberes y obligaciones que imponía el matrimonio, al concluir que la sentencia ejecutoriada que declaró el divorcio por culpa "produce una cosa juzgada material", "que alcanza inmutabilidad, conforma una realidad jurídica y material que recae en las propias partes y que tiene la fuerza suficiente para desatender la prueba rendida por la contraria" en el proceso civil indemnizatorio, y que "en todo caso, de conformidad al artículo 427 inciso final del Código de Procedimiento Civil, los hechos declarados en otro juicio (juicio de divorcio), se deben reputar verdaderos", cuestión que permitió dar "por establecidos los malos tratamientos graves, imputables al demandado, contra la integridad psíquica de la actora, acciones que fueron de tal entidad, que dieron lugar a la terminación del matrimonio por decisión jurisdiccional".

Respecto a esta última posición, manifestamos nuestra crítica al desvincularse de los daños causados por incumplimiento de los deberes conyugales para determinar los daños resarcibles que dan lugar a la obligación indemnizatoria, en circunstancias que se trata de daños originados por infracción de deberes jurídicos personales existentes entre dañador y dañado; ¿acaso el daño causado por infracción de los deberes personales del matrimonio carece de consecuencias jurídicas?; ¿ por qué limitar, condicionar la reacción del derecho, a que por incumplimiento de los deberes conyugales se perpetre un delito o falta o se lesione un derecho fundamental o se viole el deber general de no causar daño a otro?; ¿por qué privar de reparación los daños causados por la infracción de los deberes de fidelidad, respeto, cohabitación, ayuda y socorro mutuo exis- 
tentes entre demandante y demandado, cuando la misma ley reconoce a dicha infracción como causa de divorcio por culpa?

\section{De la naturaleza y presupuestos de la responsabilidad civil del cónyuge incumplidor}

Ahora bien, siguiendo aquella doctrina que entiende a los deberes conyugales como verdaderos deberes jurídicos, cuyo incumplimiento, en caso de causar daño a uno de los cónyuges, da lugar a la respectiva obligación indemnizatoria, y a la que nos adherimos y defendemos, debemos centrarnos en el estudio de sus presupuestos, a fin de precisar si por encontrarnos en el ámbito matrimonial, éstos sufren alguna modificación, es decir, si reconocen la existencia de un privilegio conyugal.

Sobre el particular, y considerando que la escasa doctrina y jurisprudencia nacional sobre el tema muy poco nos dice, creemos oportuno hacernos cargo de este apartado planteando nuestra opinión ya manifestada desde el año 2009 en adelante ${ }^{78}$, en cuanto sostenemos que sólo existe obligación de resarcir los daños causados por "incumplimiento grave o reiterado" de los deberes conyugales, cuando éstos sean imputables a "dolo o culpa grave", se acredite el nexo causal, y el camino utilizado para obtener la respectiva indemnización sea a través de las normas de la responsabilidad civil contractual; esto último, como inmediatamente veremos, en consideración a que seguimos la posición que concibe dichas normas de responsabilidad aplicables a cualquier obligación preexistente, y no sólo cuando éstas emanen de un contrato.

\section{A.- Naturaleza del resarcimiento}

Dentro de aquellos que nos manifestamos partidarios del resarcimiento de los daños causados entre cónyuges por incumplimiento de los deberes conyugales, constatamos que no existe claridad absoluta-como lo reconoce la Sentencia de la Corte de Apelaciones de Talca en su considerando undécimo-, si esta amplia referencia a la aplicación de las reglas de responsabilidad civil del derecho común, se debe entender a las reglas de la responsabilidad extracontractual, como pareciera ser la tendencia de la doctrina nacional que se ha referido sobre el particular, o contractual, como sostenemos desde una posición minoritaria, o si es necesario, incluso, "arbitrar reglas especiales para la responsabilidad civil en el Derecho de Familia, de la misma forma que estos asuntos requieren tribunales especiales y tratamiento especial", como plantea Novales Alquézar ${ }^{79}$.

\footnotetext{
78 Véase VArGas (2009).

79 Novales (2008), p. 138.
} 
Frente a esta discusión, lo que sí parece descartado desde todo punto de vista por la doctrina nacional es el empleo de las reglas de la compensación económica como el medio para resarcir los daños causados por incumplimiento de los deberes conyugales, ya que esta pretensión no tiene ninguna relación con la naturaleza y finalidad de la compensación, pese a que en un comienzo Barrientos Grandon y Novales Alquézar ${ }^{80}$ plantearan dicha posibilidad; en este mismo sentido se pronunció la Corte de Apelaciones de Santiago, en sentencia de 4 de noviembre de $2010^{81}$, al señalar en su considerando quinto, que "no es la compensación económica una institución creada para reparar este tipo de perjuicio y puede la actora, si así lo estima, perseguir la responsabilidad del demandado de acuerdo a las normas generales del Código Civil, en la sede y de acuerdo al procedimiento correspondientes, pero lo que no puede pretender es que el supuesto perjuicio que le habrían irrogado los malos tratos del demandado le sean indemnizados por la vía del artículo 61 de la Ley de Matrimonio Civil".

Ahora, para aquellos que sostienen que el camino debe ser la responsabilidad civil extracontractual, no encontramos un fundamento expreso de su decisión, sin embargo, parece encontrarse en que este estatuto sería la regla general sobre la materia, como en que el matrimonio, al carecer de naturaleza jurídica contractual, los daños originados por infracción de los deberes conyugales no pueden tener cabida dentro de la responsabilidad civil contractual, normas que reglamentarían exclusivamente la responsabilidad civil por incumplimientos contractuales.

Sobre este punto, si bien compartimos la afirmación de que el matrimonio no es un contrato, sino un negocio jurídico de Derecho de familia o acto jurídico de familia, todavía sostenemos que los daños causados por incumplimiento de sus deberes personales, de sus obligaciones jurídicas, se deben resarcir a través de la responsabilidad civil contractual, apoyados en que dichas normas no sólo son aplicables cuando la obligación violada tenga un origen contractual, sino siempre que exista entre las partes un vínculo obligacional preexistente a la propia afirmación de responsabilidad, cualquiera sea su fuente.

Sobre el particular, lo primero que debemos señalar es que la responsabilidad civil puede ser clasificada de distintas formas siguiendo distintos criterios, como por ejemplo, atendiendo a la exigencia de la culpa, en responsabilidad subjetiva u objetiva; o si emana del incumplimiento de una obligación cuya fuente sea el contrato o no, en responsabilidad contractual o extracontractual; o si entre la víctima y victimario existe un vínculo obligacional previo anterior a

80 Barrientos y Aránzazu (2004), pp. 409-410.

81 Causa rol No 890-2010. 
la afirmación o hecho que genera la responsabilidad, cualquiera sea su fuente, en responsabilidad obligacional y extraobligacional.

Que ahora bien, atendido que el Título XII del Código civil, en el cual se encuentran ubicadas las disposiciones que regulan la llamada responsabilidad contractual, lleva por título "Del efecto de las obligaciones", creemos que dicha normativa se debe aplicar siempre que entre las partes exista un vínculo obligacional preexistente, cualquiera sea la fuente de dicha obligación, ya que como hemos dicho, el legislador expresa que dicho estatuto regula el efecto de las obligaciones en general y no el efecto de los contratos en particular.

En este sentido conviene recordar las palabras de Alessandri Rodríguez ${ }^{82}$, al señalar que "la responsabilidad contractual supone necesariamente la existencia de un contrato o, a lo menos, de una obligación anterior entre las partes, ya que no es sino la sanción de su incumplimiento. Por eso creemos que sus reglas se aplican igualmente a las obligaciones cuasicontractuales, a las legales y a las precontractuales que señalamos...: todas ellas crean entre las partes un vínculo obligatorio cuya infracción origina una responsabilidad análoga a la que proviene de un contrato" ${ }^{\prime 83}$.

Es más, atendido lo expuesto, no podemos dejar de mencionar que más que hablar de responsabilidad civil contractual y extracontractual, creemos que lo correcto sería denominar a la responsabilidad civil obligacional (en vez contractual) y extraobligacional (en lugar de extracontractual), como entre otros, lo hacen en el ordenamiento español Pantaleón Prieto ${ }^{84}$ y Albaladejo ${ }^{85}$; este último, más que hablar de responsabilidad contractual, prefiere más exacto hablar de responsabilidad obligacional, que es aquella que "alcanza al deudor por no cumplir exactamente la obligación que pesa sobre él", en contraposición a la extracontractual, que debería llamarse extraobligacional, como también lo hace Beltrán de Heredia y Castaño ${ }^{86}$. En este sentido, resulta oportuno terminar citando la opinión de Lacruz Berdejo ${ }^{87}$, donde sostiene que en el caso de daños económicos o morales originados por violación de los deberes conyugales, obligaciones sin carácter patrimonial, se deben aplicar las "reglas generales sobre el

82 Alessandri (1983), pp. 58-59.

${ }^{83}$ De la misma opinión se manifiestan en el ordenamiento español JoRDANo (1987), p. 28 y ss.; RAGEL (2000b), pp. 503 y ss.; LACRUZ, et al. (2007), pp. 164 y ss.

${ }^{84}$ PantalÉon (1984), p. 1263.

85 Albaladejo (2004), p. 172.

${ }^{86}$ Beltrán (1968), p. 201. En el mismo sentido Castan (1992), p. 245, al preferir hablar de culpa obligacional en vez de culpa contractual; Espín (1983), p. 197.

${ }^{87}$ LACRUZ (1994), pp. 662 y ss.; LaCruz, et al. (1990), p. 143. 
incumplimiento de las obligaciones-las de la Ilamada culpa contractual, pero que no sólo se aplican al incumplimiento de las obligaciones contractuales".

B.- De la descripción del hecho dañoso: incumplimiento grave o reiterado de los deberes conyugales

Sobre el particular, si bien el artículo 26 y 54 de la Ley de Matrimonio Civil exigen para que se configure la causal de separación o divorcio por culpa la violación o transgresión grave de los deberes conyugales, y para ciertos causales de divorcio se agrega el requisito de la reiteración, somos de la opinión que concurriendo cualquiera de estas dos exigencias, gravedad o reiteración, se cumplirá la exigencia; en otras palabras, es necesario que el ilícito civil emane del incumplimiento grave o reiterado, por acción u omisión, de los deberes conyugales.

En este sentido, si el legislador impone la concurrencia de estos requisitos, gravedad y reiteración, para que la violación de los deberes sea causa de separación o divorcio, creemos que esa misma exigencia, ese mismo estándar, se debe aplicar para determinar cuándo ese incumplimiento puede dar origen a una acción de responsabilidad civil.

El objetivo que se busca con la exigencia de la gravedad o reiteración es evitar las acciones entre cónyuges por simples molestias o nimiedades, y con ello la proliferación de las mismas.

Nuestra posición está en armonía con el ordenamiento italiano y francés; así pues, al revisar la jurisprudencia italiana sobre el tema que nos ocupa ${ }^{88}$, observamos que en ella se estableció que el daño resarcible es el que proviene de violación grave o reiterada, descartando meras situaciones de crisis conyugal o nimiedades. En el mismo sentido se pronuncia la doctrina y jurisprudencia francesa apoyados en el art. 242 del Code, que dispone como causa del divorcio por culpa los "hechos imputables al otro cuando estos hechos constituyan una infracción grave o reiterada de los deberes y obligaciones del matrimonio...".

\section{C.- Del daño resarcible}

Sin duda este es el elemento clave, indispensable, para que las normas de responsabilidad civil puedan tener aplicación en el escenario que nos ocupa; si no se acredita la existencia de un daño ilícito, antijurídico, e imputable, patrimonial o extrapatrimonial, por mucho que exista un incumplimiento grave o reiterado, ya sea por acción u omisión de los deberes conyugales, no habrá justificación para aplicar las normas de responsabilidad civil.

${ }^{88}$ Véanse las sentencias del Tribunal de Milán de 4 de junio y 22 de noviembre, ambas del año 2002. 
Sólo el daño pone en movimiento o reacción al Derecho, cuya finalidad o función tiene carácter indemnizatorio, resarcitorio, reparatorio de los daños y perjuicios, ya sea mediante equivalencia o satisfacción, según se trate de perjuicios patrimoniales o extrapatrimoniales respectivamente, descartando cualquier función punitiva o simplemente declarativa de derechos.

Es más, debemos advertir que no basta cualquier daño, sino que éste debe ser directo, cierto, anormal, relevante, se debe comprobar la existencia de un daño objetivo imputable a otro cónyuge, en especial cuando se aleguen daños no patrimoniales; así pues, las nimiedades, las meras o simples molestias no constituyen daños resarcibles, más aún cuando en el matrimonio, atendido la convivencia de los cónyuges, al máximo grado de interrelación personal, éstos se encuentran expuestos a mayores conflictos que pueden acarrear ciertas molestias o desavenencias, pero que en ningún caso constituyen daños o perjuicios indemnizables.

Dentro de estas exigencias toma especial relevancia el hecho que solo un daño anormal, que afecta intereses relevantes, de consideración, puede dar lugar a resarcimiento. En efecto, "la noción de daño excluye aquellas incomodidades o molestias que las personas se causan recíprocamente como consecuencia normal de la vida en común... En definitiva, el daño solo da lugar a responsabilidad civil si es significativo o anormal" 89 . Dentro de las relaciones de familia es común que se produzcan altercados o diferencias, los cuales eventualmente provocan perjuicios, sin embargo, estos daños son consecuencia del diario vivir de los miembros de una familia, por lo que mal podría dar lugar a una acción indemnizatoria. Estimamos que solo un daño significativo y anormal proveniente de un incumplimiento grave o reiterado puede dar lugar a la reparación.

Por último, debemos tener presente que, aunque normalmente serán los daños extrapatrimoniales los más demandados por incumplimiento grave o reiterado de los deberes conyugales, los daños patrimoniales causados por esta infracción también deben ser resarcidos; así, por ejemplo, serán indemnizables los alimentos entregados por un padre a un hijo que resultó ser de otro, los costos médicos para la comprobación de la paternidad, los costos médicos y farmacéuticos por los tratamientos psicológicos y psiquiátricos, entre otros.

D.- De la relación de causalidad entre el perjuicio y el incumplimiento grave o reiterado de los deberes conyugales

Prácticamente no hay autor que no señale el nexo causal como un presupuesto imprescindible no solo de la responsabilidad por culpa, sino también

89 Barros (2007), p. 226. 
objetiva. "La causalidad expresa el más general fundamento de justicia de la responsabilidad civil, porque la exigencia mínima para hacer a alguien responsable es que exista una conexión entre su hecho y el daño" ${ }^{\prime \prime 0}$.

Resulta complejo definir qué es lo que se entiende por nexo causal, pues corresponderá a la postura que se adopte en esta materia, cuestión que excede los límites de este trabajo, no obstante podemos decir que entre un acto ilícito y un determinado daño hay relación causal cuando el primero engendra el segundo y éste no puede darse sin aquel, es decir, cuando el hecho doloso o culposo es la causa directa y necesaria del daño ${ }^{91}$.

Ahora, de los diversos estudios realizados por la doctrina sobre las distintas teorías que intentan explicar los criterios que se deben seguir para determinar si un hecho es o no causa de un acontecimiento posterior, como también los límites de la obligación resarcitoria, hoy en día se reconoce la preferencia de la teoría de la causalidad adecuada, que permite atribuir objetivamente al autor del hecho las consecuencias "adecuadas" al evento dañoso, en función a un criterio de posibilidades y probabilidades de un resultado, según lo que generalmente acontece conforme la experiencia habitual, según lo que cualquier hombre razonable podía haber previsto ${ }^{92}$, relación de causalidad que comprende siempre un juicio anterior y desvinculado a una imputación subjetiva a título de culpa ${ }^{93}$.

Además, se debe tener presente que al acreditar la relación de causalidad, ésta puede ser interrumpida por el caso fortuito o fuerza mayor o por la intervención de un tercero, constituyendo una eximente de responsabilidad civil, o incluso por la propia conducta o culpa de la víctima, en cuyo caso servirá como una medida para reducir el quantum resarcitorio o hasta para eximir de responsabilidad.

\section{E.- Del criterio de imputación de responsabilidad del agente dañoso}

Nuestro ordenamiento jurídico establece como regla general un sistema de responsabilidad subjetivo, que exige culpa o dolo del autor daño, exigencia que resulta plenamente aplicable a los daños causados por incumplimiento de los deberes conyugales. Dicho esto, corresponde en este apartado analizar

\footnotetext{
90 Barros (2007), p. 373.

91 RAMOS (2008), p. 102.

92 Como expresa Larenz (1958), p. 200, "en este punto no interesa el conocimiento y previsión personal del responsable del daño, sino la apreciación hecha según la experiencia media de un juzgador u observador perspicaz, para el que, en el momento de ocurrir el hecho generador de la responsabilidad, fueran cognoscibles ya todas las circunstancias, y no solamente las que sean notorias (el denominado pronóstico objetivo ulterior)"; en el mismo sentido De Cossıo (1966), pp. 531 y ss.
}

93 LARENZ (1958), p. 201. 
este presupuesto dentro de las relaciones conyugales, determinando cuál es el grado de diligencia que se exige a los cónyuges, y cuyo incumplimiento genera la obligación de indemnizar.

Al revisar esta cuestión, lo que primero que constatamos es que la ley no ha precisado el nivel de diligencia que ha de prestarse en el cumplimiento de los deberes conyugales, por lo que creemos que debemos aplicar aquella que constituye la regla general, esto es, la del buen padre de familia, modelo objetivo o abstracto y externo.

Sin embargo, el modelo abstracto y externo del buen padre de familia se debe concretar a través del criterio de adaptación del verdadero modelo dispuesto, atendiendo a las exigencias de la naturaleza de la obligación (a los deberes de fidelidad, respeto, cohabitación, ayuda y socorro mutuo, donde se entremezclan prestaciones de dar, hacer y no hacer, personales, y de Derecho de familia), al carácter intuito personae del matrimonio (donde las circunstancias de las personas son conocidas y expresamente "aceptadas" por matrimonio), como por la convivencia a que da lugar (donde las personas se comportan e interaccionan tal como son, de acuerdo con sus aptitudes naturales y adquiridas, sin sujeción a especiales deberes de precaución), consideraciones subjetivas que nos llevan a estimar que la diligencia del buen padre de familia se rebaja o degrada, concretándose en un modelo de conducta que obliga a los cónyuges sólo a responder de los daños causados por dolo o culpa grave ${ }^{94}$.

Nuestra postura se reafirma, además, al constatar que los preceptos que expresamente consagran reglas que obligan a responder en el ámbito familiar, establecen dicha obligación en la medida que se acredite dicho grado de imputación, como acontece en los artículos 257, 328, 1748, 1768, todos del Código Civil, cuestión que nos lleva a concluir que si legislador estableció en estos casos expresamente la imputabilidad en el dolo o culpa grave, es porque de una u otra forma está fijando esta regla o estándar de imputación para el ámbito familiar.

En este sentido, al fijar en la culpa grave o dolo el grado de imputación exigible para dar lugar a la reparación de los daños causados por incumplimiento de los deberes conyugales, estamos morigerando las consecuencias de la aplicación del Derecho de daños al ámbito matrimonial, resguardando la unidad y paz familiar, evitándose acciones indemnizatorias fundadas en meros descuidos ${ }^{95}$.

${ }^{94}$ Badosa (1987), p. 295; el autor señala que ésta es la única interpretación que permite unificar y armonizar el art. 1104 del Código Civil en su conjunto.

95 En el mismo sentido opinan para el ordenamiento español RodríGuez Guitían (2009), p. 133; MARíN (2004); MARín (2006), pp. 160 y ss.; en el mismo sentido para el ordenamiento argentino MEDINA (1999), p. 71. 
No se trata de construir una regla de inmunidad conyugal, sino de reconocer la existencia de un "privilegio conyugal", que limita la responsabilidad entre los cónyuges por los daños causados por incumplimiento de los deberes conyugales, imputables a dolo o culpa grave, evitando con ello judicializar cualquier clase de incumplimientos.

En el caso del matrimonio, no cabe duda que no sólo la identidad de la persona del contrayente es esencial, sino que también sus "cualidades personales", las cuales son conocidas y expresamente "aceptadas" por matrimonio, como se demuestra al ser un negocio jurídico intuito personae, donde el error en la identidad como en las cualidades personales, atendida la naturaleza o los fines del matrimonio, son causas de nulidad por falta de consentimiento según el artículo $8^{\circ} \mathrm{N}^{\circ} 1$ y $\mathrm{N}^{\circ} 2$ de la Ley de Matrimonio Civil.

Además, no debemos olvidarnos que el grado de diligencia que deben observar los cónyuges en el cumplimiento de los deberes se desarrolla bajo un escenario de convivencia conyugal, donde las personas se comportan e interaccionan tal como son, de acuerdo con sus aptitudes naturales y adquiridas, sin sujeción a especiales deberes de precaución. La propia intimidad propicia que la persona adopte una actitud relajada y favorece el desarrollo de la libertad personal sin particulares restricciones. A esta libertad se corresponde el deber entre cónyuges de aceptar a cada cual con sus cualidades y defectos, sin poder exigir a los demás una conducta más precavida que la que adoptan en sus propios asuntos, lo que justifica que en este tipo de relaciones se aplique un estándar de diligencia subjetiva, a diferencia de lo que ocurre en el tráfico y en la mayoría de actividades de la vida social, donde los estándares de precaución son objetivos, en las relaciones de convivencia se tienen en cuenta aptitudes y limitaciones individuales ${ }^{96}$.

Es más, creemos que esta disminución de los niveles de diligencia, este "privilegio conyugal", no es particular del matrimonio, sino que es una regla o principio del Derecho de familia en general, ya que, como hemos señalado, en los casos en que el legislador estableció reglas expresas de responsabilidad civil en el ámbito familiar, fijó el estándar de imputación en el dolo o culpa grave.

Por último, al establecer la imputación de la responsabilidad de los cónyuges en el dolo o culpa grave, ésta se constituye en una herramienta más, que unida a la exigencia de gravedad o reiteración del incumplimiento del deber conyugal que causa el daño, contribuye a evitar la proliferación de demandas de reparación entre cónyuges, preocupación que constituye un fundamento más para aquellos que sostienen la irresarcibilidad de los daños causados por incumplimiento de los deberes conyugales.

${ }^{96}$ En este sentido se pronuncia en España Ferrer (2001), p. 11; y en Italia Bona (2003), pp. 444 y ss. 


\section{Conclusiones}

Que el incumplimiento de los deberes conyugales puede causar daños a los cónyuges con independencia de que esta infracción pueda motivar o no la presentación de una demanda de separación o divorcio. La fuente del daño es el incumplimiento del deber, mas no la acción de separación o divorcio que es una facultad legal.

Que no resulta válido para sostener la irresarcibilidad de los daños en el caso que nos ocupa, la discutida calidad de obligación de los deberes conyugales fundado en su preeminencia ético-moral por sobre la jurídica, como en su falta de coercibilidad o imposibilidad de cumplimiento compulsivo, toda vez que los deberes personales del matrimonio son deberes jurídicos, aunque tengan un fuerte componente ético y moral; esta última característica en ningún caso les priva de juridicidad. Consecuencia de esta afirmación es que frente al incumplimiento de dichos deberes se producen efectos jurídicos, y si de ellos se causa un daño, no existe impedimento para aplicar el principio general de responsabilidad que obligue a su reparación.

Que, de la misma forma, el hecho que estemos frente a deberes jurídicos imposibles de perseguir su cumplimiento forzadamente desde su inicio no niega ni impide el ejercicio de la acción indemnizatoria, ya que esta situación no es exclusiva de los deberes conyugales, sino que también se extiende a otros casos, como se observa en todas las obligaciones de hacer intuito personae, sin que por ello se les prive de su juridicidad o de la acción resarcitoria en caso de incumplimiento.

Que la especialidad del Derecho de familia como argumento para rechazar una acción indemnizatoria por daños causados por incumplimiento de los deberes conyugales carece de toda fundamentación, ya que en nuestro medio existe un principio general de responsabilidad que abarca todo el ordenamiento jurídico, y del cual el Derecho de familia no está excluido; en efecto, no habiendo una norma que prohíba, restrinja o limite la aplicación del principio general de responsabilidad, no existe fundamento que deje al margen de este principio al Derecho de familia en general, y al vínculo matrimonial en particular, por lo que si a consecuencia del incumplimiento de un deber conyugal se causa un daño, éste debe ser indemnizado.

Que como resultado de las reformas introducidas en nuestro Derecho de familia, se ha producido una extensión del carácter contractualista de sus instituciones, que obligan a reinterpretar sus principios y límites conforme a la nueva concepción de la familia, la cual, hoy en día, pone su acento en la persona, en términos tales que la familia no significa la pérdida o renuncia de sus derechos individuales, lo que es coherente con la protección misma que entrega la Constitución a la persona. 
Que incluso aquellos que sostienen la irresarcibilidad de los daños por incumplimiento de los deberes conyugales, admiten la reparación de los daños entre cónyuges cuando éste tiene su origen en un delito o falta, o la infracción de un derecho fundamental, o la infracción del deber general de no causar daño a otro, ya provenga el delito o falta o infracción del incumplimiento de un deber conyugal o no.

Que aceptado el resarcimiento de los daños causados por incumplimiento de los deberes conyugales, la doctrina mayoritaria se inclina por aplicar las normas de la responsabilidad civil extracontractual, aunque advertimos que discrepamos de dicha opinión; en efecto, somos partidarios de utilizar el estatuto de responsabilidad contractual, que debiese llamarse obligacional, ya que sus normas se aplican siempre que entre dañante y dañado exista un vínculo jurídico previo a la afirmación de responsabilidad, ya tenga por fuente el contrato, el cuasicontrato o la ley.

Que en materia de presupuestos de responsabilidad, sostenemos que sólo existe obligación de resarcir los daños causados por incumplimiento grave o reiterado de los deberes conyugales, cuando éstos sean imputables a dolo o culpa grave reconociendo la existencia de un "privilegio conyugal", se acredite el nexo causal, y el daño que se reclame sea directo, cierto, anormal, relevante, evitando la proliferación de demandas resarcitorias por meras nimiedades o simples molestias.

\section{BiBLIOGRAFÍA CITADA}

Abeliuk Manasevich, René (1983): Las obligaciones, segunda edición (Santiago, Ed. Ediar Editores Ltda.).

Albaladejo, Manuel (2002): Curso de Derecho Civil IV, Derecho de familia, novena edición (Barcelona, Bosch).

Albaladejo, Manuel (2004): Derecho civil, duodécima edición (Madrid, Edisofer), t. II, Derecho de obligaciones.

Alessandri Rodríguez, Arturo (1941): Derecho Civil (Santiago, Ed. Zamorano y Caperán), t. I, Derecho de Familia.

AlesSANDri Rodríguez, Arturo (1983), De la responsabilidad extracontractual en el Derecho civil chileno, segunda edición (Santiago, Ediar Editores Ltda.), t. I.

Alonso Pérez, Mariano (1992): “Dialéctica entre fidelidad matrimonial y libertad sexual: el delito de violación entre esposos separados y el llamado debito conyugal", en: Estudios de Derecho Civil en homenaje el profesor Dr. José Luis Lacruz Berdejo (Barcelona, Bosch), volumen I.

BADOSA Coll, Ferran (1987): La diligencia y la culpa del deudor en la obligación civil (Bolonia, Ed. Publicaciones del Real Colegio de España). 
Barrientos Grandon, Javier y Aránzazu Novales, Alquézar (2004): Nuevo Derecho Matrimonial Chileno, ley No 19.947: Celebración del matrimonio, separación, divorcio y nulidad, segunda edición (Santiago, LexisNexis).

Barros Bourie, Enrique (2007): Tratado de Responsabilidad Extracontractual, primera edición (Santiago, Editorial Jurídica de Chile).

Beltrán De Heredia y Castaño, José (1968): "Concepto de fraude civil", Conferencia pronunciada en la Academia Matritense del Notariado el día 29 de marzo de 1965, en: Anales de la Academia Matritense del Notariado, t. XVI. BénABent, Alain (1988): Droit civil, La famille, troisième édition (Paris, Litec).

BOnA, M. (2003): "Famiglia e responsabilità civile: la tutela resarcitoria nelle relazioni parentali", en: G. Cassano (Director), Manuale del nuovo diritto di famiglia, seconda edizione (Piacenza, Ed. Casa Editrice La Tribuna).

Boulanger, Francois (1990): Droit civil de la famille, (Económica, Paris), t. I, Aspects Internes et Internationaux.

Castan Tobeñas, José (1992): Derecho civil español, común y foral, decimosexta edición, revisada y puesta al día por Gabriel García Cantero (Madrid, Reus, S.A.), t. III, Derecho de obligaciones, La obligación y el contrato en general.

Claro Solar, Luis (1978): Explicaciones de Derecho civil chileno y comparado, segunda edición (Santiago, Editorial Jurídica de Chile), t. II, De las personas.

Cornu, Gérard (2001): Droit civil, La Famille, $7^{\circ}$ édition (Paris, Montchrestien).

Corral TalCianı, Hernán (2008): "Adaptación de la responsabilidad civil en los procesos de familia. La experiencia chilena de la 'Compensación económica' en caso de nulidad matrimonial y divorcio", en: Ars Boni et Aequi $\left(N^{\circ} 4\right)$, pp. 81-89.

Corral Talciani, Hernán (2011): Separación, nulidad y divorcio, Análisis desde los principios y las reglas de la Ley de Matrimonio Civil (Santiago, Ed. Abeledo Perrot-Thomson Reuters).

Court Murasso, Eduardo (2004): Nueva Ley de matrimonio civil, ley No 19.947 de 2004 Analizada y Comentada (Colombia, Legis).

De Cossío y Corral, Alfonso (1966): La causalidad en la responsabilidad civil: Estudio del Derecho español, en: ADC, t. XIX, pp. 527-554.

De Verda y BeAmOnte, José Ramón (2007): "Responsabilidad civil y divorcio en el derecho español: resarcimiento del daño moral derivado del incumplimiento de los deberes conyugales", en: Diario La ley, NNo6676, 21 de marzo. Disponible en: http://www.laley.net.

Díez Picazo y Ponce De León, Luis (1962): "El negocio jurídico del Derecho de Familia", en: Revista General de Legislación y Jurisprudencia ( ${ }^{\circ}$ 6), pp. 771-792. 
Doglotтl, M. (1982): "Le persone fisique", en: Pietro Rescigno (Direttore), Trattato di diritto privato, 2. Persone e famiglia (Torino, Utet), tomo primo.

Domínguez Hidalgo, Carmen (2005a): "Los principios que informan el derecho de familia chileno: su formulación clásica y su revisión moderna", en: Revista Chilena de Derecho (volumen XXII, No 2), pp. 205-218.

Domínguez Hidalgo, Carmen (2005b): Seminario: Compensación económica en la Nueva Ley de Matrimonio Civil, organizado por el Colegio de Abogados de Chile A.G.

Dutтo, Ricardo (2007): Daños ocasionados en las relaciones de familia (Buenos Aires, Hammurabi).

EnneCCerus, Ludwig; KIPP, Theodor y WolfF, Martin (1953): Tratado de Derecho civil, segunda edición (Traducc. de la $20^{\circ}$ edición alemana por Blas Pérez González y José Alguer, Barcelona, Bosch), t. IV Derecho de familia, volumen I, El matrimonio.

Espín Cánovas, Diego (1983): Manual de Derecho civil español, sexta edición revisada y ampliada (Madrid, Editorial Revista de Derecho Privado), Volumen III, Obligaciones y contratos.

FERRER RiBA, Josep (2001): "Relaciones familiares y límites del derecho de daños", en: InDret 04/2001. Disponible en: http://www.indret.com/pdf/065_es.pdf [visitado el 8/07/2014].

Ferrer Riba, Josep (2003): "Relaciones familiares y límites del derecho de daños", en: Antonio Cabanillas Sánchez et al. (Comité Coordinador), Estudios Jurídicos en homenaje al profesor Luis Díez-Picazo (Madrid, Thomson-Cívitas), t. II, Derecho civil, Derecho de obligaciones.

Fraccon, Adalgisa (2001): "Comentario a la sentencia del Tribunale di Milano, 10 febbrario 1999", en: Il diritto di famiglia e delle persone (volumen XXX, luglio-setiembre).

García Cantero, Gabriel (2005): "Chile estrena divorcio", en: Actualidad Civil $\left(\mathrm{N}^{\circ} 5\right)$.

HAUSER, Jean (1999): en: Revue Trimestrielle de Droit Civil (No 4, octubre/décembre).

Hauser, Jean (2005): en: Revue Trimestrielle de Droit Civil (No 1, enero/ marzo).

Herane Vives, Francisco (2006): "Reparación por incumplimiento de los deberes matrimoniales", en: Estudios de Derecho Civil II (Santiago, LexisNexis), pp. 181-194.

Hernández Paulsen, Gabriel (2014): "Responsabilidad civil por daños causados entre cónyuges. Especial referencia a la infracción de los deberes conyugales" (artículo inédito facilitado por el autor). 
JANA L., Andrés y TAPIA R., Mauricio (2004): “Daño moral en la responsabilidad contractual a propósito de un fallo de la Corte Suprema de 5 de noviembre de 2001", en: Cuadernos de Análisis Jurídicos. Colección Derecho Privado ( N 1 ), pp. 171-209.

JoRdAno FraGa, Francisco (1987): La responsabilidad contractual (Madrid, Cívitas, S.A.).

Lacruz Berdejo, José Luis (1994): "Comentario al artículo 68", revisado para la $2^{\circ}$ edición por Joaquín Rams Albesa y Jesús Delgado Echeverría, en: José Luis Lacruz Berdejo (Coord.), Matrimonio y divorcio, Comentarios al Título IV del Libro Primero del Código Civil, segunda edición (Madrid, Civitas).

LaCruz Berdejo, José Luis et al. (1990): Elementos de Derecho Civil IV, Derecho de familia, tercera edición actualizada (Barcelona, José María Bosch Editor S.A.), volumen I.

Lacruz Berdejo, José Luis et al. (2007): Elementos de Derecho Civil II, Derecho de obligaciones, cuarta edición revisada y puesta al día por Francisco Rivero Hernández (Madrid, Dykinson), volumen I, Parte general. Teoría general del contrato.

LARENZ, Karl (1958): Derecho de obligaciones (Madrid, Ed. Editorial Revista de Derecho Privado), t. I, versión española y notas de Jaime Santos Briz.

Larroucau García, María Matilde (2010a): "Incumplimiento de las obligaciones conyugales y en especial del deber de fidelidad como fuente generadora de responsabilidad civil. A propósito de un fallo pronunciado por el Tribunal Superior de Justicia de Brasil", en: Revista Chilena de Derecho de Familia (No 2), pp. 99-124.

Larroucau García, Matilde (2010b): "Responsabilidad civil en Derecho de Familia", en: Revista Chilena de Derecho de Familia (No 2), pp. 147-226.

Llamas Pombo, Eugenio (2007): "Divorcio y responsabilidad civil", en: Práctica Derecho de Daños, Revista de Responsabilidad Civil y Seguros (año V, № 49).

Marín García De Leonardo, María Teresa (2004): “¿Cabe la indemnización de daños y perjuicios por incumplimiento de deberes conyugales?", en: Sentencias de TSJ y AP y Otros Tribunales núm. 15/2004, Parte Estudio, (BIB 2004/1732). Disponible en: http://www.westlaw.es.

Marín García De Leonardo, María Teresa (2006): "Remedios indemnizatorios en el ámbito de las relaciones conyugales", en: José Ramón De Verda y Beamonte (Coord.), Daños en el Derecho de Familia, Revista de Derecho Patrimonial ( ${ }^{\circ}$ 17), Monografía Asociada a Revista Aranzadi de Derecho Patrimonial, Thomson-Aranzadi, pp. 147-177.

MARKESINIS, B.S. (1994): A comparative introduction to the German Law of torts, third edition (Oxford, Clarendon Press). 
Martinic Galetovic, María Dora y Weinstein Weinstein, Graciela (2004): "Nuevas tendencias de las uniones conyugales de hecho", en: Bárbara Urrejola Scolari (Coord.), Instituciones de Derecho de familia (Santiago, LexisNexis).

Medina, Graciela (1999): "Daño extrapatrimonial en el Derecho de Familia y el Proyecto de Código Civil unificado de 1998", en: Revista de Derecho de Daños (Santa Fe, Rubinzal-Culzoni).

Medina, Graciela (2008): Daños en el derecho de familia, segunda edición actualizada (Santa Fe, Rubinzal-Culzoni Editores).

Novales AlquÉzar, Aránzazu (2008): "Responsabilidades especiales. ¿Debiera haber en el Derecho matrimonial mecanismos reparatorios?", en: Regímenes especiales de responsabilidad civil, Cuadernos de Análisis Jurídicos. Colección Derecho Privado IV, pp. 119-150.

PantalÉOn Prieto, Fernando (1984): "Comentario a SSTS de 26 de enero de 1984", en: Cuadernos Cívitas Jurisprudencia Civil ( $\mathrm{N}^{\circ}$ 4, enero-marzo).

PizARRo Wilson, Carlos (2007): "La responsabilidad contractual en derecho chileno", Fabricio Mantilla y Francisco Ternera, Los contratos en el Derecho privado (Bogotá, Legis Colombia).

Ragel SÁnchez, Luis Felipe (2000a): "Denegación de indemnización del daño moral causado por infidelidad matrimonial", en: Cuadernos Cívitas Jurisprudencia Civil (t. 52, enero-marzo), pp. 153-163.

Ragel Sánchez, Luis Felipe (2000b): Estudio legislativo y jurisprudencial del Derecho civil: obligaciones y contratos (Madrid, Dykinson).

Ramos Pazos, René (2007): Derecho de Familia, séptima edición actualizada (Santiago, Editorial Jurídica de Chile), t. I.

Ramos Pazos, René (2008): De las Obligaciones (Santiago, LegalPublishing).

ReINA, Víctor y MARTINelL, Josep (1995): Curso de derecho matrimonial (Madrid, Marcial Pons, Ediciones Jurídicas S.A.).

RocA I TRÍAs, Encarna (2000): "La responsabilidad civil en el Derecho de familia. Venturas y desventuras de cónyuges, padres e hijos en el mundo de la responsabilidad civil", en: Juan Antonio Moreno Martínez (coord.), Perfiles de la Responsabilidad civil en el nuevo milenio (Madrid, Dykinson), pp. 531-563.

Rodríguez Grez, Pablo (2012): Inexistencia y nulidad en el Código civil chileno. Teoría bimembre de la nulidad (Santiago, Editorial Jurídica de Chile), Volumen I.

Rodríguez Guitián, Alma María (2003): "Función de la responsabilidad civil en determinadas relaciones de convivencia: daños entre cónyuges y daños entre los miembros de la pareja de hecho", en: Revista de Derecho Patrimonial (No 10), pp. 65-94. 
Rodríguez Guitían, Alma María (2009): Responsabilidad Civil en el Derecho de Familia: Especial referencia al ámbito de las relaciones paterno-filiales (Madrid, Editorial Aranzadi).

Rodríguez Pinto, María Sara (2012): "Indemnización de perjuicios por infracción al deber de fidelidad en el matrimonio", en: El Mercurio Legal, 25 de julio. Disponible en: http://www.elmercurio.com/Legal/Noticias/AnalisisJuridico/2012/07/25/Indemnizacion-de-perjuicios-por-infraccion-al-deberde-fidelidad-en-el-matrimonio.aspx [visitado el 8/07/2014].

Romero Coloma, Aurelia María (2000): "¿Genera responsabilidad civil la violación de los artículos 67 y 68 del Código Civil?", en: RC Revista de Responsabilidad Civil, Circulación y Seguro (noviembre).

Sancho Villarreal, Luis (2001): "El deber de fidelidad conyugal como obligación jurídica y consecuencias de su infracción", en: Revista de Derecho de familia ( $\left.\mathrm{N}^{\mathrm{O}} 11\right)$.

Savigny (1878): Sistema del Derecho Romano Actual (traducido del alemán por Ch. Guenoux, vertido al castellano por Jacinto Mesía y Manuel Poley, Madrid, Góngora y Compañía), t. I.

Savigny (1908): La escuela Histórica del Derecho, documentos para su estudio (traducido del alemán por R. Atard, Madrid, Librería General de Victoriano Suárez).

Severín Fuster, Gonzalo (2008): "Indemnización entre cónyuges por los daños causados con ocasión del divorcio", en: Estudios de Derecho Civil III (Valparaíso, LegalPublishing), pp. 99-140.

Somarriva Undurraga, Manuel (1983): Derecho de Familia, $2^{\circ}$ edición (Santiago, Ediar Editores Ltda.).

TOMASELlo HART, Leslie (1969): El daño moral en la responsabilidad contractual (Santiago, Editorial Jurídica de Chile).

Turner Saelzer, Susan (2012): "Deberes personales derivados del matrimonio y daños en la jurisprudencia chilena", en: Estudios de Derecho Civil VIII (Santa Cruz, LegalPublishing), pp. 165-173.

Valenzuela Del Valle, Jimena (2012): "Responsabilidad civil por el incumplimiento de obligaciones matrimoniales y por el ejercicio abusivo del divorcio unilateral. Un estudio de su admisibilidad en Chile", en: Revista de Derecho, Universidad Católica del Norte, Sección Estudios (año 19, № 1), pp. 241-269.

Vargas Aravena, David (2006): "La responsabilidad civil en el matrimonio: Problemática en el ordenamiento español y su eventual aplicación al sistema chileno", en: Gaceta Jurídica (№ 312), pp. 7-36.

Vargas Aravena, David (2009): Daños civiles en el matrimonio (España, La LeyGrupo Wolters Kluwer). 
VélIz MölleR, Patricio (2004): Divorcio, nulidad y separación. Los caminos frente a la ruptura (Santiago, Cerro Manquehue).

Veloso Valenzuela, Paulina (2011): Tratado de jurisprudencia y doctrina. Derecho de Familia (Santiago, Thomson Reuters), t. I.

Vidal Olivares, Álvaro (2004): “La compensación económica en la Ley de Matrimonio Civil ¿Un nuevo régimen de responsabilidad civil extracontractual?", en: Revista de Derecho. Universidad de Concepción (№ 215-216), pp. 265-287.

Vodanovic H., Antonio (1961): Curso de Derecho Civil (Santiago, Ed. Nascimento), t. I, volumen I.

ZATTI, Paolo (1982): "I diritti e i doveri che nascono dal matrimonio e la separazione dei coniugi", en: Pietro Rescigno (Direttore), Trattato di diritto privato, 3. Persone e famiglia (Torino, Ed. Utet), tomo secondo. 